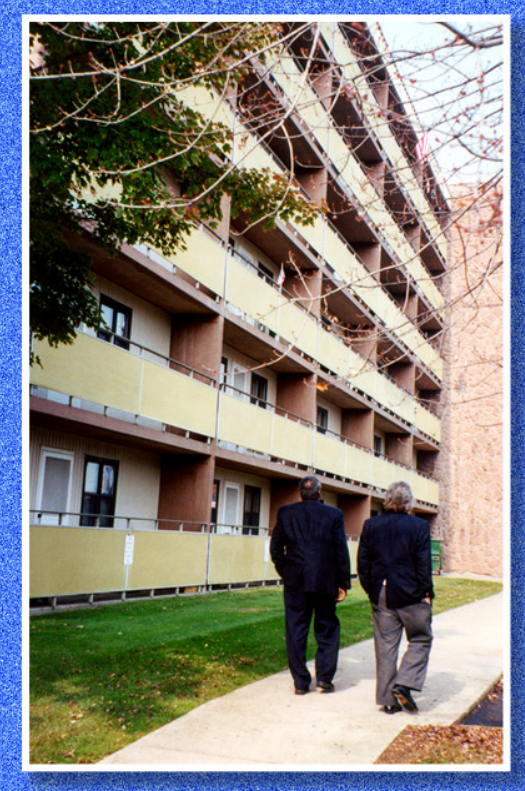

1999 - 2002 Public Housing Partnership: U.S. Department of Housing and Uriban Development and U.S. Department of Energy



February 2003
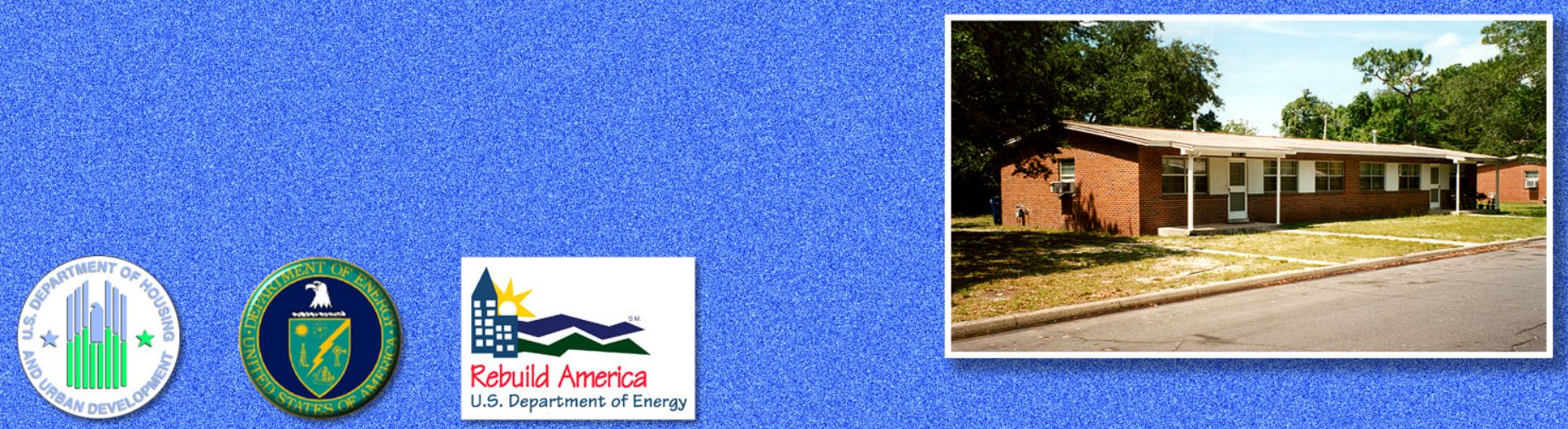


\section{DOCUMENT AVAILABILITY}

This report may be electronically downloaded from the Oak Ridge National Laboratory from the following source:

Web Site: http://lib1.isd.ornl.gov:8182/TSEARCH/BASIS/tidd/fqma/tpsext/SF

Reports produced after January 1, 1996, are generally available free via the U.S. Department of Energy (DOE) Information Bridge:

Web Site: http://www.osti.gov/bridge

Reports produced before January 1, 1996 may be purchased by members of the public from the following source:

National Technical Information Service

5285 Port Royal Road

Springfield, VA 22161

Telephone: 703-605-6000 (1-800-553-6847)

TDD: $703-487-4639$

Fax: 703-605-6900

E-mail: info@ntis.fedworld.gov

Web site: http://www.ntis.gov/support/ordernowabout.htm

Reports are available to DOE employees, DOE contractors, Energy Technology Data Exchange (ETDE) representatives, and international Nuclear Information System (INIS) representatives from the following source:

Office of Scientific and Technical Information

P.O. Box 62

Oak Ridge, TN 37831

Telephone: $865-576-8401$

Fax: 865-576-5728

E-mail: reports@adonis.osti.gov

Web site: http://www.osti.gov/contact.html

This report was prepared as an account of work sponsored by an agency of the United States government. Neither the United States government nor any agency thereof, nor any of their employees, makes any warranty, express or implied, or assumes any legal liability or responsibility for the accuracy, completeness, or usefulness of any information, apparatus, product, or process disclosed, or represents that its use would not infringe privately owned rights. Reference herein to any specific commercial product, process, or service by trade name, trademark, manufacturer, or otherwise, does not necessarily constitute or imply its endorsement, recommendation, or favoring by the United States government or any agency thereof. The views and opinions of authors expressed herein do not necessarily state or reflect those of the United States government or any agency thereof. 


\title{
1999-2002 Public Housing Partnership: U.S. Department of Housing and Urban Development and U.S. Department of Energy
}

\author{
Mark P. Ternes \\ Oak Ridge National Laboratory \\ Oak Ridge, Tennessee \\ Matthew Pesce \\ Aspen Systems Corporation \\ Rock Hill, South Carolina \\ Rick Diamond \\ Lawrence Berkeley National Laboratory \\ Berkeley, California
}

February 2003

Prepared for the

U.S. Department of Housing and Urban Development Office of Public and Indian Housing Office for Public Housing and Voucher Programs

Public Housing Management and Occupancy Division 



\section{Contents}

List of Figures and Tables $\ldots \ldots \ldots \ldots \ldots \ldots \ldots \ldots \ldots \ldots \ldots \ldots \ldots \ldots \ldots \ldots$

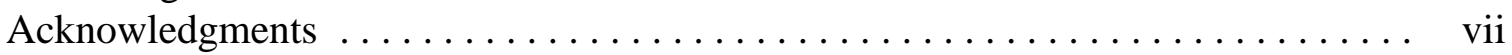

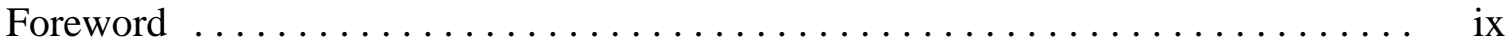

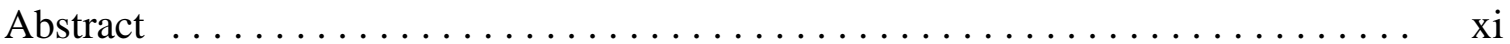

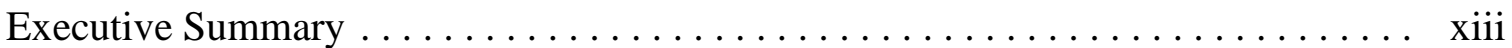



INTRODUCTION $\ldots \ldots \ldots \ldots \ldots \ldots \ldots \ldots \ldots \ldots \ldots \ldots \ldots \ldots \ldots \ldots \ldots$

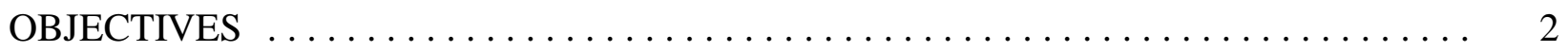

REBUILD AMERICA PARTNERSHIPS $\ldots \ldots \ldots \ldots \ldots \ldots \ldots \ldots \ldots \ldots \ldots$

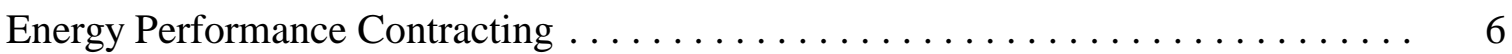

Energy Efficiency Upgrades, Retrofits, and Rehabilitations . . . . . . . . . . 6

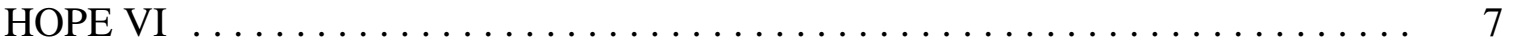

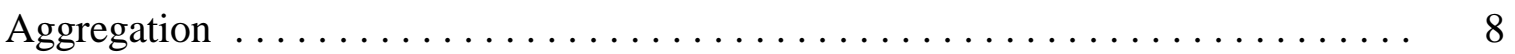

Collaborations with the DOE Weatherization Assistance Program . . . . . . . . . . 9

CONFERENCES, WORKSHOPS, AND TRAINING $\ldots \ldots \ldots \ldots \ldots \ldots \ldots \ldots \ldots \ldots$

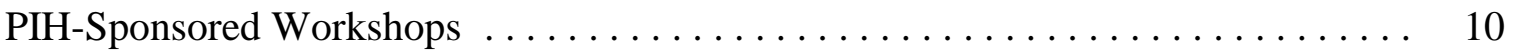

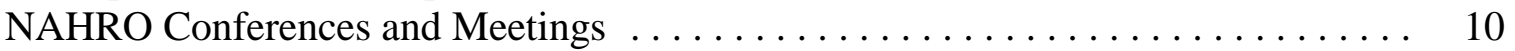

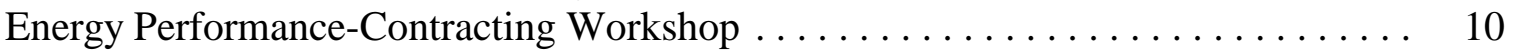

Affordable Comfort's High-Performance Public Housing Workshop . . . . . . . . . . . . 12

ASSISTANCE TO THE OFFICE OF PUBLIC AND INDIAN HOUSING $\ldots \ldots \ldots \ldots \ldots$

CONCLUSIONS AND RECOMMENDATIONS $\ldots \ldots \ldots \ldots \ldots \ldots \ldots \ldots \ldots \ldots$

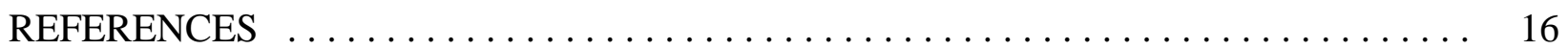

APPENDIX A: SUMMARY OF PUBLIC HOUSING PARTNERSHIP ACTIVITY $\ldots \ldots \ldots$

APPENDIX B: SUMMARY OF CONFERENCES, WORKSHOPS, AND TRAINING . . 37 



\section{Figures and Tables}

Figure

1. Forty-three partnerships were established in all parts of the United States

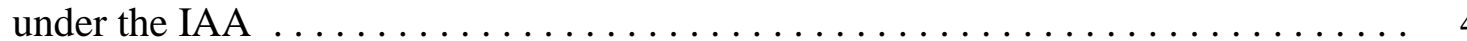

\section{Tables}

ES.1. Rebuild America partnerships involved with the 1999-2002 HUD-DOE Interagency Agreement $\ldots \ldots \ldots \ldots \ldots \ldots \ldots \ldots \ldots \ldots \ldots \ldots \ldots \ldots \ldots$

1. Rebuild America partnerships involved with the 1999-2002

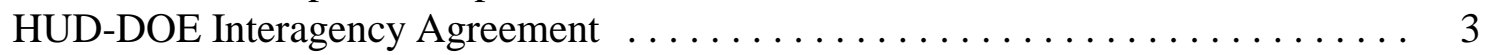

2. Status of projects initiated under the IAA $\ldots \ldots \ldots \ldots \ldots \ldots \ldots \ldots \ldots \ldots$

3. Housing authorities implementing an energy performance contract $\ldots \ldots \ldots \ldots$

4. Housing authorities installing conservation measures $\ldots \ldots \ldots \ldots \ldots \ldots$

5. Conferences, workshops, and training $\ldots \ldots \ldots \ldots \ldots \ldots \ldots \ldots \ldots \ldots$

A.1. Active Rebuild America public housing partnerships $\ldots \ldots \ldots \ldots \ldots \ldots$ 



\section{Acknowledgments}

The authors wish to acknowledge the U.S. Department of Housing and Urban Development (HUD) Office of Public and Indian Housing (PIH) staff and programs that made this partnership between HUD and the U.S. Department of Energy (DOE) possible. Sonia Burgos, currently a Special Assistant in the Office for Public Housing and Voucher Programs, provided the foresight and leadership in establishing the Interagency Agreement (IAA) as director of the former Community Safety and Conservation Division, Office for Public and Assisted Housing Delivery, before HUD's reorganization in 2002. Dick Santangelo, Public Housing Management and Occupancy Division, Office for Public Housing and Voucher Programs, has been a true stalwart in guiding the partnership over the past year and promoting the benefits of the partnership and energy efficiency within HUD PIH.

The authors also wish to acknowledge the contributions of Mark Bailey and Dan Sze of DOE in establishing and carrying out the partnership. Both were instrumental in working with Sonia Burgos to bring the IAA to fruition within DOE, and Dan provided program guidance and support throughout the term of the partnership.

The authors are especially grateful to the Rebuild America team, which makes Rebuild America work throughout the nation and without which this IAA could not have been implemented. The Rebuild America team members, who are too numerous to name individually, include the program representatives, state energy office personnel, DOE headquarters staff, support staff, business partners, strategic partners, and the community of partnerships who carry out the day-today activities involved with partnership development, support, and implementation. 



\section{Foreword}

This report provides a summary of the activity performed by the U.S. Department of Energy (DOE) between 1999 and 2002 in its partnership with the U.S. Department of Housing and Urban Development (HUD) on public housing. It was prepared to help HUD headquarters staff and others understand the breadth of activities performed and to guide future collaborations.

This report was also written to help motivate public housing authorities to initiate energy efficiency projects of their own by demonstrating that energy efficiency projects can be successfully performed and completed in public housing. Staff of public housing authorities and others working directly with public housing agencies should read this report to learn from their peers the types of projects that have been performed and the means of financing and implementing them, and then decide which technologies and approaches are pertinent to their own needs. 



\section{Abstract}

In December 1999, the U.S. Department of Housing and Urban Development (HUD) entered into an Interagency Agreement (IAA) with the U.S. Department of Energy (DOE) and its Rebuild America Program to promote conservation and reduce utility costs in public housing through forums, research, demonstration, and evaluation. The IAA was effectively implemented from November 2000 to December 2002. Under the IAA, Rebuild America established 31 new partnerships with public housing authorities, started 6 new partnerships with organizations that focus on public housing, and initiated new projects with 6 existing Rebuild America public housing partnerships. These 43 partnerships directly involved 51 public housing authorities in 77 energy-related projects (several of the 43 partnerships involved multiple housing authorities and projects). Rebuild America assistance on these projects encompassed a wide range of activities, including planning assistance on energy management and capital investment, reviews of utility consumption and metering options, assistance in implementing HUD's energy incentives, design reviews and energy analyses, and assistance in the development of energy projects and resident programs. In addition, Rebuild America made presentations to housing authorities on energy efficiency opportunities and solutions and provided energy training on selected topics at 23 conferences and workshops that impacted many more housing authorities. This report provides an overview of the accomplishments achieved under the IAA; describes the 77 projects that have been completed, are under way, or are planned; and summarizes the presentations and training provided. 



\section{Executive Summary}

In December 1999, HUD's Office of Public and Indian Housing (PIH) entered into an Interagency Agreement (IAA) with the U.S. Department of Energy (DOE) and its Rebuild America Program to promote conservation and reduce utility costs in public housing through forums, research, demonstration, and evaluation. The IAA was effectively implemented from November 2000 to December 2002.

The primary objective of the IAA was to establish Rebuild America partnerships with public housing authorities that would demonstrate how energy efficiency and water conservation can be successfully implemented. Under the IAA, Rebuild America established 31 new partnerships with public housing authorities, started 6 new partnerships with organizations that focus on public housing, and initiated new projects with 6 existing Rebuild America public housing partnerships (see Table ES.1). These 43 partnerships directly involved 51 public housing authorities in 77 energy-related projects (several of the 43 partnerships involved multiple housing authorities and projects). Rebuild America assistance on these projects encompassed a wide range of activities, including

- planning assistance on energy management and capital investment,

- reviews of utility consumption and metering options,

- assistance in implementing HUD's energy incentives,

- design reviews and energy analyses, and

- assistance in the development of energy projects and resident programs.

Sixteen housing authorities initiated a performance contract, and five more are investigating its applicability to their authority. Other partnership projects and workshops are helping to initiate and support additional energy performance contracts. For example, the state of Colorado partnership is actively working with housing authorities in the state on performance contracting, and the Louisiana Department of Natural Resources is creating a revolving pool of capital to help fund energy performance contracts.

Rebuild America provided direct technical assistance to several of these housing authority projects by reviewing the requests for qualifications (RFQs) to select energy service companies or the audit agreement between a housing authority and the energy service company. In addition, Rebuild America provided technical assistance to the states of Colorado and Louisiana to help them implement their programs.

Rebuild America also co-sponsored week-long energy performance-contracting workshops in 2001 and 2002 attended by 43 and 47 people, respectively. These two workshops provided training to housing authorities as well as HUD officials on the details of performance contracting and the nuances of adhering to HUD regulations governing the performancecontracting process. Similar workshops had been provided in 1999 and 2000. Twenty of the 33 housing authorities whose representatives attended the workshops given between 1999 and 2001 have issued RFQs to initiate implementation of a performance contract. Over the four years, HUD staff from 11 field offices have received training.

Eight housing authorities are installing or have completed the installation of conservation measures in ten projects using funding 
Table ES.1. Rebuild America partnerships involved with the 1999-2002 HUD-DOE Interagency Agreement

\begin{tabular}{|c|c|c|c|c|}
\hline Type of partnership & $\begin{array}{c}\text { No. of } \\
\text { partnerships }\end{array}$ & \multicolumn{3}{|c|}{ Partnerships } \\
\hline $\begin{array}{l}\text { New partnership } \\
\text { with public housing } \\
\text { authority }\end{array}$ & 31 & $\begin{array}{l}\text { Akron, OH } \\
\text { Albany, NY } \\
\text { Albuquerque, NM } \\
\text { Annapolis, MD } \\
\text { Berlin, NH } \\
\text { Binghamton, NY } \\
\text { Buffalo, NY } \\
\text { Cumberland, MD } \\
\text { Gastonia, NC } \\
\text { Hagerstown, MD } \\
\text { Houston, TX } \\
\end{array}$ & $\begin{array}{l}\text { Kansas City, MO } \\
\text { Keene, NH } \\
\text { Lucas, OH } \\
\text { Meriden, CT } \\
\text { Miami-Dade, FL } \\
\text { Newark, NJ } \\
\text { Newport News, VA } \\
\text { Niagara Falls, NY } \\
\text { Oakland, CA } \\
\text { Panama City, FL }\end{array}$ & $\begin{array}{l}\text { Rahway, NJ } \\
\text { Rockford, IL } \\
\text { San Antonio, TX } \\
\text { Somersworth, NH } \\
\text { Springfield, MO } \\
\text { Tacoma, WA } \\
\text { Tallahassee, FL } \\
\text { Troy, NY } \\
\text { Virgin Islands } \\
\text { Wilson, NC }\end{array}$ \\
\hline $\begin{array}{l}\text { New partnership } \\
\text { with organization } \\
\text { focused on public } \\
\text { housing }\end{array}$ & 6 & \multicolumn{3}{|c|}{$\begin{array}{l}\text { New York State Energy Research and Development Authority (NYSERDA) } \\
\text { Non-Profit Housing Association of Northern California } \\
\text { Pacific Southwest Regional Alliance (CA and NV) } \\
\text { Seattle Regional Office (DOE) } \\
\text { State of Colorado } \\
\text { State of Louisiana }\end{array}$} \\
\hline $\begin{array}{l}\text { Existing public } \\
\text { housing authority } \\
\text { partnership }\end{array}$ & 6 & $\begin{array}{l}\text { Asheville, NC } \\
\text { Austin, TX } \\
\text { Boston, MA }\end{array}$ & $\begin{array}{l}\text { Chicago, IL } \\
\text { District of Columbia } \\
\text { Stark, OH }\end{array}$ & \\
\hline
\end{tabular}

Note: The 43 partnerships are described in more detail in Appendix A of this report.

mechanisms other than energy performance contracting, such as their modernization capital or funds provided by HUD through its additional operating subsidy energy incentive. For example, the Stark Metropolitan Housing Authority installed numerous conservation measures (including geothermal heat pumps) while converting efficiency apartments to onebedroom units, performed a complete energy upgrade of a high-rise building, and replaced 2000 refrigerators and electric stoves with gas models. The housing authorities of Binghamton and Troy, New York, are leveraging the resources available through the New York State Energy Research and Development Authority (NYSERDA) system benefit services to incorporate energy efficiency practices and measures into their buildings.

HUD's HOPE VI Program was developed to eradicate severely distressed public housing. Rebuild America has teamed with the Boston,
Hagerstown, Oakland, and Tacoma Housing Authorities and the Miami-Dade Housing Agency to improve the energy efficiency of their HOPE VI projects. Both the Hagerstown Housing Authority and the Miami-Dade Housing Agency are striving to achieve housing designs that meet ENERGY STAR ${ }^{\circledR}$ requirements.

Rebuild America and DOE worked with the Miami-Dade Housing Agency to exemplify the use of design charrettes in HOPE VI projects by cosponsoring the charrette and providing energy experts and industry personnel to attend the charette and review design plans. Rebuild America also performed energy modeling for the Hagerstown Housing Authority and made several design recommendations on the basis of the modeling.

In addition to the state of Louisiana partnership previously described, three 
partnerships are implementing aggregation projects that demonstrate a broader application of HUD's energy incentives and improved approaches to energy management, especially in small housing authorities.

- Stark Metropolitan Housing Authority organized a purchasing group with six other Ohio housing authorities to purchase natural gas at below-market rates and to take advantage of HUD's rate-reduction energy incentive.

- Rebuild America brought together the Keene Housing Authority with two other New Hampshire housing authorities-Somersworth and the Town of Lebanon-in a collaboration to implement a joint energy performance contract. Rebuild America guided them through the aggregation process and assisted in the development of the joint RFQ.

- DOE's Seattle Regional Office and the Washington HUD Office of Public Housing initiated a cooperative pilot project to develop an aggregated, standardized procurement for conducting energy audits, performing engineeringbased utility allowance calculations, and employing utility tracking software in public housing authorities.

Establishing collaborations between public housing authorities and local agencies that implement the DOE Weatherization Assistance Program was an initial interest in the IAA and remains a focus of HUD today. The state of Colorado initiated a new effort through its Rebuild Colorado Program to focus state efforts on the public and assisted housing market sector. In addition to promoting performance contracting within the state's housing authorities, this effort is also linking public housing authorities to local weatherization agencies and the State Weatherization Office. Rebuild America provided technical assistance to the state in starting up this effort and forged a relationship between the state and the local HUD field office. The Chicago Housing Authority was awarded a HUD Resident Opportunity and Self-Sufficiency Program (ROSS) grant to train public housing residents in weatherization skills and help them establish a resident-owned business. In a similar program that the Chicago authority implemented before the IAA, a similar business was hired by the local weatherization program to perform some of its weatherization work.

In fulfillment of additional objectives of the IAA, Rebuild America made presentations to housing authorities on energy efficiency opportunities and solutions and provided energy training on selected topics at 23 conferences and workshops. In addition to making presentations at ten National Association of Housing and Redevelopment Officials (NAHRO) conferences, Rebuild America organized energy sessions at two PIH-sponsored workshops-the Resident Leader Training Conference in Dallas in April 2001 and the PHA Staff Training Conference in Washington DC in August 2001. These sessions focused on what resident leaders can do to help in energy conservation, and how housing authorities can manage their energy costs and train residents to conserve energy. Rebuild America also worked with HUD's Healthy Homes Program and others to sponsor a full-day workshop at the 2002 Affordable Comfort Conference on high-performance public housing. The workshop brought together 50 individuals from around the United States to address issues of healthy and energy-efficient public housing, and how health issues are intertwined with energyefficiency conditions and improvements. 
The work performed under the IAA demonstrates that energy efficiency projects can be successfully implemented and utility costs lowered in public housing. The IAA also showed that DOE programs-in particular, the Rebuild America and Weatherization Assistance Programs — offer natural linkages and opportunities to work with public housing authorities. Several major actions were identified to continue the efforts started under the IAA and achieve the energy goals desired by HUD:

- The successes achieved under the IAA and by others need to be thoughtfully documented and effectively communicated in order to improve energy education and increase action within housing authorities.

- Existing Rebuild America partnerships with public housing authorities and associated organizations need continued support. Additional partnerships focusing on key energy approaches that HUD wants to feature and promote (e.g., aggregation, collaboration with the DOE

Weatherization Assistance Program, use of ENERGY STAR equipment and programs) should be developed to help make these approaches mainstream within the public housing authority community.

- A focus group with representation from all principal parties needs to be convened to help streamline the performancecontracting process for public housing authorities.

- An ongoing assessment of performance contracting should be initiated to verify and document past performance, monitor the activity, and guide future efforts.

- Methods of encouraging HOPE VI award winners to achieve energy-efficient designs should be formulated and the means by which housing authorities can achieve energy-efficient designs should be developed.

- Methods need to be developed to allow HUD to better manage its public housing energy program, including an energy database and an energy benchmarking procedure specific to public housing. 


\section{Abbreviations and Acronyms}

$\begin{array}{ll}\text { CEE } & \begin{array}{l}\text { Consortium for Energy Efficiency } \\ \text { domestic hot water }\end{array} \\ \text { DHW } & \text { U.S. Department of Energy } \\ \text { housing authority } \\ \text { HA } & \text { U.S. Department of Housing and Urban Development } \\ \text { IAA } & \text { Interagency Agreement } \\ \text { NAESCO } & \text { National Association of Energy Service Companies } \\ \text { NAHRO } & \text { National Association of Housing and Redevelopment Officials } \\ \text { NCAT } & \text { National Center for Appropriate Technology } \\ \text { NYSERDA } & \text { New York State Energy Research and Development Authority } \\ \text { PHA } & \text { public housing authority } \\ \text { PHADA } & \text { Public Housing Authority Directors Association } \\ \text { PHAS } & \text { Public Housing Assessment System } \\ \text { PIC } & \text { Public and Indian Housing Information Center } \\ \text { PIH } & \text { HUD Office of Public and Indian Housing } \\ \text { RFP } & \text { request for proposals } \\ \text { RFQ } & \text { request for qualifications } \\ \text { ROSS } & \text { HUD Resident Opportunity and Self-Sufficiency Program } \\ \text { WAP } & \text { DOE Weatherization Assistance Program }\end{array}$





\section{Introduction}

The U.S. Department of Housing and Urban Development (HUD) spent about $\$ 846$ million in 1999 for energy in its approximately 1.3 million public housing units, and another \$308 million for water (HUD 2000). In addition, the residents of public housing themselves spent approximately $\$ 250$ million in additional energy costs. Public housing authorities spend, on average, about onequarter of their operating budgets on utilities. Because reductions in utility costs will increase housing affordability, resources for community investment, and resident asset retention, HUD has been interested in better ways for housing authorities to manage and reduce utility and operating costs, and lessen their demand for energy.

The HUD Office of the Inspector General (HUD 1995) reviewed the opportunities to reduce utility costs for public housing authorities and concluded that "opportunities for reducing utility costs continue to exist and are cost effective in many instances due to ongoing improvements in technology." The review noted that "while housing authorities have responsibility for managing utility costs, HUD can help housing authorities take advantage of the opportunities by encouraging information exchange and training and by addressing other impediments to the use of the opportunities."
In 1998 the Senate Appropriations Committee requested that HUD determine the utility costs in public housing authorities and develop recommendations and strategies for addressing excess costs. One strategy proposed as an outcome of this work was to "utilize the resources of the Department of Energy's Rebuild America Program ... for providing information, training, and technical assistance to HAs [housing authorities]" (HUD 1999). Subsequently, in December 1999, HUD entered into an Interagency Agreement (IAA) with the U.S. Department of Energy (DOE) and DOE's Rebuild America Program to promote conservation and reduce utility costs in public housing through forums, research, demonstration, and evaluation. The IAA was effectively implemented from November 2000 to December 2002.

The work performed under this IAA represents a continuation of past partnerships between DOE and HUD to improve the energy efficiency of public housing. The DOE-HUD partnership that was in effect between 1990 and 1995 resulted in 27 projects that were designed to share the results of DOE research with housing providers throughout the nation, reduce energy costs in federally subsidized dwelling units, and improve their affordability and comfort (Brinch 1996). Nine of these 27 projects focused on public housing. 


\section{Objectives}

The primary objective of the partnership established between HUD and DOE's Rebuild America Program was to establish 20 to 28 new Rebuild America partnerships with public housing authorities to demonstrate how energy efficiency and water conservation can be successfully implemented within public housing. In addition, the projects implemented by these partnerships can serve as case studies for how public housing authorities can address energy and water issues.

Under the partnership agreement, DOE was to make presentations at HUD-sponsored conferences and provide guidance and support to HUD's Office of Public and Indian Housing $(\mathrm{PIH})$ on an as-needed basis.

These objectives were consistent with other public housing activities identified in HUD's five-year energy plan (HUD 1999), which included the following:
- "Encourage HAs to implement energysaving activities and provide assistance to HAs in using their reserves, capital funds, the incentives provided by Section 118 of the Housing Act of 1987, and reflecting the Appropriations Act of 1998 with regard to energy performance contracting."

- "Provide training and technical assistance in the implementation of energy performance contracting."

- “Train PHAs [public housing authorities] on the economics of purchasing higher efficiency equipment."

- "Continue to encourage and assist HAs to train residents in energy efficiency. Share with residents the benefits of savings derived from their cooperation ... Encourage the use of Section 3 Training, Employment, Contracting, and Subcontracting authority to promote resident economic development in the energy area." 


\section{Rebuild America Partnerships}

Since November 2000, Rebuild America has established 31 new partnerships with public housing authorities and 6 new partnerships with organizations that focus on public housing. In addition, 6 existing Rebuild America public housing partnerships initiated new projects pertinent to the objectives of the IAA and supported under this effort. These 43 partnerships, listed in Table 1, were established in all parts of the United States, as shown in Fig. 1.

Because some of the 43 partnerships involved multiple housing authorities and performed multiple projects, a total of 51 public housing authorities were directly involved in 77 energy-related projects impacted by Rebuild America's work under the IAA. Numerous other housing authorities were indirectly affected by the IAA through attendance at the energy performance-contracting workshops offered by Rebuild America, participation in organizations focusing on public housing that were in partnership with Rebuild America, and attendance at conference sessions organized or presented by Rebuild America.

Table 2 summarizes the 77 projects initiated under the IAA. Most of the projects are completed (18) or under way (35), with some still in the planning stage (24). Appendix A provides a narrative of the projects performed by each partnership and the assistance provided by Rebuild America. Table A.1 provided in Appendix A summarizes the activity performed by each partnership and

Table 1. Rebuild America partnerships involved with the 1999-2002 HUD-DOE Interagency Agreement

\begin{tabular}{|c|c|c|c|c|}
\hline Type of partnership & $\begin{array}{c}\text { No. of } \\
\text { partnerships }\end{array}$ & \multicolumn{3}{|c|}{ Partnerships } \\
\hline $\begin{array}{l}\text { New partnership } \\
\text { with public housing } \\
\text { authority }\end{array}$ & 31 & $\begin{array}{l}\text { Akron, OH } \\
\text { Albany, NY } \\
\text { Albuquerque, NM } \\
\text { Annapolis, MD } \\
\text { Berlin, NH } \\
\text { Binghamton, NY } \\
\text { Buffalo, NY } \\
\text { Cumberland, MD } \\
\text { Gastonia, NC } \\
\text { Hagerstown, MD } \\
\text { Houston, TX }\end{array}$ & $\begin{array}{l}\text { Kansas City, MO } \\
\text { Keene, NH } \\
\text { Lucas, OH } \\
\text { Meriden, CT } \\
\text { Miami-Dade, FL } \\
\text { Newark, NJ } \\
\text { Newport News, VA } \\
\text { Niagara Falls, NY } \\
\text { Oakland, CA } \\
\text { Panama City, FL }\end{array}$ & $\begin{array}{l}\text { Rahway, NJ } \\
\text { Rockford, IL } \\
\text { San Antonio, TX } \\
\text { Somersworth, NH } \\
\text { Springfield, MO } \\
\text { Tacoma, WA } \\
\text { Tallahassee, FL } \\
\text { Troy, NY } \\
\text { Virgin Islands } \\
\text { Wilson, NC }\end{array}$ \\
\hline $\begin{array}{l}\text { New partnership } \\
\text { with organization } \\
\text { focused on public } \\
\text { housing }\end{array}$ & 6 & \multicolumn{3}{|c|}{$\begin{array}{l}\text { New York State Energy Research and Development Authority (NYSERDA) } \\
\text { Non-Profit Housing Association of Northern California } \\
\text { Pacific Southwest Regional Alliance (CA and NV) } \\
\text { Seattle Regional Office (DOE) } \\
\text { State of Colorado } \\
\text { State of Louisiana }\end{array}$} \\
\hline $\begin{array}{l}\text { Existing public } \\
\text { housing authority } \\
\text { partnership }\end{array}$ & 6 & $\begin{array}{l}\text { Asheville, NC } \\
\text { Austin, TX } \\
\text { Boston, MA }\end{array}$ & $\begin{array}{l}\text { Chicago, IL } \\
\text { District of Columbia } \\
\text { Stark, OH }\end{array}$ & \\
\hline
\end{tabular}

Note: The 43 partnerships are described in more detail in Appendix A of this report. 


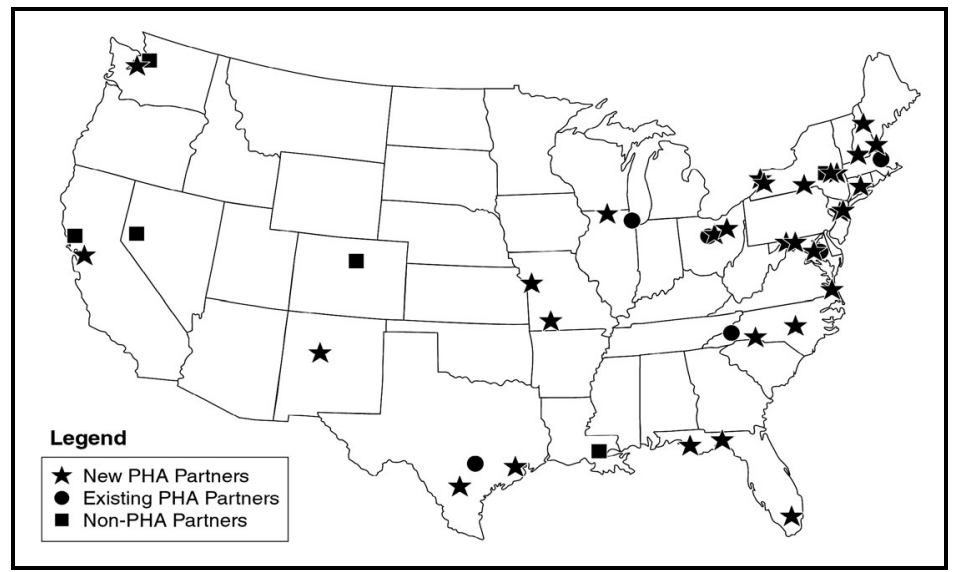

Fig. 1. Forty-three partnerships were established in all parts of the United States under the IAA.

Table 2. Status of projects initiated under the IAA

\begin{tabular}{|c|c|c|c|c|}
\hline \multirow{2}{*}{ Project } & \multicolumn{3}{|c|}{ No. of projects } & \multirow{2}{*}{ Total } \\
\hline & Completed & Under way & Planned & \\
\hline Energy performance contracting & & $15^{1 / 2^{a, b, c}}$ & 5 & $20^{1 / 2}$ \\
\hline Installation of energy and water conservation measures & 6 & 4 & $10^{1} 2^{d}$ & $201 / 2$ \\
\hline Audits/master plans & 6 & 1 & 1 & 8 \\
\hline HOPE VI & & 5 & & 5 \\
\hline Aggregation & $1 / 2^{e}$ & $1^{b, c}$ & 1 & $2 \frac{1}{2}$ \\
\hline Utility purchases/rate-reduction incentive & $2^{1 / 2^{e}}$ & & 1 & $31 / 2$ \\
\hline Work with DOE Weatherization Assistance Program & & $1 \frac{1}{2^{a}}$ & $1 / 2^{d}$ & 2 \\
\hline Resident education/training & 1 & $1 \frac{1 / 2^{f}}{2}$ & 3 & $51 / 2$ \\
\hline Advanced technologies & 1 & 1 & 2 & 4 \\
\hline Meter conversions & & 1 & & 1 \\
\hline Health issues & & $1 \frac{1 / 2}{f}$ & & $1 \frac{1}{2}$ \\
\hline Other & 1 & 2 & & 3 \\
\hline All projects & 18 & 35 & 24 & 77 \\
\hline
\end{tabular}

${ }^{a}$ Includes a dual category project with the state of Colorado promoting energy performance contracting and working with the DOE Weatherization Assistance Program.

${ }^{b}$ Includes a dual category project with Keene and Somersworth Housing Authorities involving performance contracting and aggregation.

${ }^{c}$ Includes a dual category project with the state of Louisiana involving establishing a loan fund to promote performance contracting and aggregation of housing authorities.

${ }^{d}$ Includes a dual category project with the Kansas City Housing Authority involving working with the DOE Weatherization Assistance Program to install wall insulation.

${ }^{e}$ Includes a dual category project with the Stark Metropolitan Housing Authority involving aggregating housing authorities to purchase natural gas.

${ }^{f}$ Includes a dual category project with the Oakland Housing Authority involving resident education on health issues. 
categorizes the activity by the type of financing involved, actions taken, and technology areas involved.

Rebuild America assistance on these projects encompassed a wide range of activities, including

- $\quad$ planning assistance on energy management and capital investment,

- reviews of utility consumption and metering options,

- assistance in implementing HUD's energy incentives,

- design reviews and energy analyses, and

- assistance in the development of energy projects and resident programs.

A brief summary and highlights of some of these projects is described in the remainder of this section. Lessons learned from these projects include the following:

- Successful projects are led internally within the housing authority. In the absence of an energy champion within the housing authority, energy projects are not initiated. Also, if the energy champion leaves the housing authority, current and future energy projects stop.

- Internal departments within housing authorities-operations, maintenance, development, modernization-do not effectively coordinate planning across their program areas, especially in larger authorities.

- HUD interprets and applies energy incentives and performance-contracting regulations inconsistently from state to state. Delays in obtaining waivers to HUD regulations to allow some projects to occur (e.g., projects involving fuel conversions or tenants that pay for their own utilities) and other required approvals from HUD effectively halt energy projects financed using HUD's energy incentives.

- Housing authorities involved with recurring activities such as energy audits, utility allowance calculations, refrigerator purchases, requests to utilize HUD's additional operating subsidy or ratereduction energy incentives, and performance contracting could benefit tremendously from standardized requests for proposals (RFPs) or requests for qualifications (RFQs), contract documents, submitals, etc. Some of these already exist for performance contracting.

- Small housing authorities (defined by HUD as those having fewer than 500 public housing units) are too numerous for all to receive direct technical assistance and would benefit from the establishment of collaboration mechanisms. Projects undertaken by such authorities are typically too small to attract energy service companies and other private-sector assistance. Government programs on the local, state, and national levels (such as Rebuild America and programs within state energy offices) can be responsive to some small housing authorities, but not to all.

- Housing authorities receiving HOPE VI funds must struggle to make their building designs energy efficient because first cost issues often out weigh life-cycle considerations.

- Key housing authority personnel remain unaware of the energy opportunities and solutions available within their housing authority. 


\section{Energy Performance Contracting}

Implementing an energy performance contract was the most common single means of improving energy efficiency chosen by the partnerships under the IAA. Sixteen housing authorities initiated a performance contract, and five more are investigating the applicability of performance contracting to their authority (see Table 3). Because of the time needed to initiate a performance contract and complete the installation of measures, no performance contracts were completed (in repayment) during the time frame of the IAA. However, three partnerships-Boston, Chicago, and Oakland Housing Authoritiescompleted performance contracts before the IAA was initiated. These early adopters of this new financing approach have helped in training other housing authorities. The Tallahassee Housing Authority also initiated a performance contract during the IAA period before becoming a Rebuild America partner.

Table 3. Housing authorities implementing an energy performance contract

\begin{tabular}{ll|l}
\hline \multicolumn{2}{c|}{ Under way } & \multicolumn{1}{c}{ Planned } \\
\hline Albuquerque & Newark & Akron \\
Asheville & Newport News & Boston \\
Austin & Niagara Falls & District of Columbia \\
Boulder $^{a}$ & Rahway & Gastonia \\
Chicago & Rockford & Lucas \\
Houston & San Antonio & \\
Keene & Somersworth & \\
Meriden & Virgin Islands & \\
\hline
\end{tabular}

${ }^{a}$ Affiliated with the state of Colorado partnership.

The energy performance-contracting workshop offered by Rebuild America for public housing authorities (discussed in the next chapter) was a primary means of helping housing authorities. The workshop provided housing authority staff with the knowledge and tools needed to implement an energy performance contract on their own. In a few partnerships, Rebuild America provided direct technical assistance by reviewing the RFQ to select an energy service company or the audit agreement between a housing authority and the energy service company.

Some partnership projects are helping to initiate more energy performance contracts beyond those directly involved with Rebuild America. The state of Colorado and the Pacific Southwest Alliance partnerships are actively working with, or providing training to, housing authorities on performance contracting. These initiatives should lead to additional performance-contracting projects in the future. The state of Louisiana Department of Natural Resources is creating a revolving pool of capital to help fund energy performance contracts (see the discussion in this chapter under "Aggregation").

\section{Energy Efficiency Upgrades, Retrofits, and Rehabilitations}

Eight housing authorities (see Table 4) are installing or have completed the installation of conservation measures in ten projects using funding mechanisms other than energy performance contracting, such as the organization's modernization capital or funds provided by HUD through its additional operating subsidy energy incentive.

Conservation measures installed in these

Table 4. Housing authorities installing conservation measures

\begin{tabular}{l|l|ll}
\hline Completed & Under way & \multicolumn{2}{|c}{ Planned } \\
\hline Akron & Akron & Annapolis & Kansas City \\
Berlin & Binghamton & Chicago & Oakland \\
Cumberland & Panama City & Cumberland (2) & Springfield \\
Stark (3) & Troy & Gastonia & Wilson \\
& & Hagerstown (2) \\
\hline
\end{tabular}


projects include windows, insulation, heating system upgrades, water-saving devices, air conditioners, refrigerators, and other appliances. These were installed-either individually or in combination with other measures - as building retrofits or while buildings were being upgraded or undergoing extensive rehabilitation. Nine more housing authorities (see Table 4) have similar work planned for the future in 11 projects.

The efforts of several housing authorities are noteworthy.

- Stark Metropolitan Housing Authority installed numerous conservation measures (including geothermal heat pumps) while converting efficiency apartments to onebedroom units. These measures were funded, in part, through HUD's additional operating subsidy energy incentive. The housing authority also performed a complete energy upgrade of a high-rise building using its Comprehensive Grant funds and replaced 2000 refrigerators and electric stoves with gas models using HUD's additional operating subsidy energy incentive.

- Binghamton and Troy Housing Authorities are leveraging the resources available through the New York State Energy Research and Development Authority (NYSERDA) system benefit services to incorporate energy efficiency practices and measures into their buildings. For example, the Binghamton Housing Authority is replacing heating systems in its row houses as part of an integrated operating and maintenance/design process that will serve as a case study for NYSERDA for this approach.

\section{HOPE VI}

The HOPE VI Program was developed to eradicate severely distressed public housing. HOPE VI revitalization grants can change the physical shape of public housing by funding the demolition of severely distressed public housing and the capital costs of major rehabilitation, new construction, and other physical improvements. HOPE VI provides the opportunity to build energy-efficient public housing from the outset, thereby ensuring greater comfort, improved indoor air quality, and low utility costs for the housing authority, HUD, and residents.

Rebuild America teamed with the Boston, Hagerstown, Oakland, and Tacoma Housing Authorities and the Miami-Dade Housing Agency to improve the energy efficiency of their HOPE VI projects. Both the Hagerstown Housing Authority and Miami-Dade Housing Agency are striving to achieve housing designs that meet ENERGY STAR ${ }^{\circledR}$ requirements. Processes needed to achieve this goal - selecting developers that have a commitment to energy-efficient design and that start with energy-efficient design specifications; performing energy modeling to find the most economical means of improving the energy design; and tapping into the expertise of energy experts and the energy industry through design charrettes-were exemplified by these two projects. The Boston, Oakland, and Tacoma Housing Authorities are just beginning their design efforts, with the Tacoma Housing Authority emphasizing sustainable as well as energyefficient design.

Rebuild America and DOE assisted the Miami-Dade Housing Agency in its efforts by co-sponsoring the design charrette and providing energy experts and industry personnel to attend the design charrette and review design plans. Rebuild America 
performed energy modeling for Hagerstown Housing Authority's HOPE VI designs and made several design recommendations on the basis of the modeling.

\section{Aggregation}

Although only four projects dealt with aggregation, they are all noteworthy because they demonstrated first-of-a-kind approaches to aggregation that allowed a broader application of HUD's energy incentives and improved approaches to energy management, especially in small housing authorities.

Stark Metropolitan Housing Authority organized a purchasing group with six other Ohio housing authorities (Lucas, Loraine, Zanesville, Portage, Jefferson, and Harrison Metropolitan Housing Authorities) to purchase natural gas at below-market rates and to take advantage of HUD's rate-reduction energy incentive to keep half of the cost savings within the housing authorities. The first annual contract, signed in June 2001, averaged about $12 \%$ below market rate. This project is also noteworthy because Stark Metropolitan Housing Authority served as a conduit/mentor for these smaller housing authorities to take advantage of market purchase of natural gas and HUD's ratereduction energy incentive even though Stark Metropolitan Housing Authority could have done this as easily on its own.

Keene Housing Authority collaborated with the Somersworth Housing Authority and the Town of Lebanon Housing Authority to implement an energy performance contract. They issued their RFQ to select an energy service company in May 2002. In general, small housing authorities have not been able to use performance contracting because energy service companies do not find projects in small housing authorities to be attractive (overhead costs per investment dollar are high, savings potential is small, and total project costs are low). Through aggregation, Keene and Somersworth Housing Authorities were able to team with the Town of Lebanon Housing Authority to offer a combined project of about 800 housing units, which was attractive to an energy service company. Rebuild America helped bring these three housing authorities together, guided them through the aggregation process, and assisted in the development of the joint RFQ.

The state of Louisiana Department of Natural Resources created a revolving loan fund backed by state-issued bonds for energy conservation projects. Five housing authorities in the state have requested loans under the energy fund to implement energy performance contracts. By aggregating the source of capital for housing authorities, the state of Louisiana is able to provide cheaper financing that will allow more and broader projects to be cost effective. Rebuild America worked with the state of Louisiana on defining this innovative financing concept and ways to implement it.

DOE's Seattle Regional Office and the Washington HUD Office of Public Housing initiated a cooperative pilot project to develop an aggregated, standardized procurement process for conducting energy audits and performing engineering-based utility allowance calculations. The pilot will demonstrate how housing authorities in Washington, Oregon, and Idaho can receive accurate, detailed audits and utility allowance calculations by aggregating their procurements and developing thorough RFP documents. A second pilot will also be performed to develop a standardized procurement process for purchasing utility-tracking software. This software will simplify utility reporting under the HUD Performance Funding System and allow a housing authority to better manage its utility costs. This second pilot will also explore the use of standardized utility data to 
focus technical assistance and training on those authorities with the highest consumption or energy intensity and better methods for representing utilities in the Public and Indian Housing Information Center (PIC) database and Public Housing Assessment System (PHAS) financial indicators.

\section{Collaborations with the DOE Weatherization Assistance Program}

Establishing collaborations between public housing authorities and local agencies that implement the DOE Weatherization Assistance Program was one of the IAA's initial interests and remains a focus of HUD today. The state of Colorado initiated a new effort through its Rebuild Colorado Program to focus state efforts on the public and assisted housing market sector. In addition to promoting performance contracting within the state's housing authorities, this effort also links public housing authorities to local weatherization agencies and the State Weatherization Office. Examples of collaborations between weatherization agencies and public housing authorities already existed in the state, and the State
Weatherization Office believes that working with public housing authorities on all of its housing (public and assisted) is a logical business move that will benefit all parties. Rebuild America provided information on energy issues and opportunities in public housing to the state of Colorado and helped them establish a relationship with the local HUD field office.

The Chicago Housing Authority was awarded a HUD Resident Opportunity and Self-Sufficiency Program (ROSS) grant to train public housing residents in weatherization skills and help them establish a resident-owned business. In a similar program that the Chicago Housing Authority implemented before the IAA, a similar business was hired by the local weatherization program to perform some of its weatherization work.

The Gastonia Housing Authority is also working with its local weatherization provider, and the Kansas City Housing Authority is exploring working with its local weatherization agency to install wall insulation in developments that were previously renovated but did not receive energy improvements. 


\section{Conferences, Workshops, and Training}

During the term of the IAA, Rebuild America made presentations to housing authorities on energy efficiency opportunities and solutions and provided energy training on selected topics at 23 conferences and workshops. Table 5 provides a listing of these activities, and Appendix B provides details on each event. Most of these meetings were also used to help market the Rebuild America Program and solicit housing authorities to join Rebuild America as partners. Four comprehensive actions are especially noteworthy.

\section{PIH-Sponsored Workshops}

Rebuild America organized energy sessions at two PIH-sponsored workshops - the Resident Leader Training Conference in Dallas in April 2001 and the PHA Staff Training Conference in Washington D.C. in August 2001. These sessions focused on how resident leaders can help in energy conservation, and how housing authorities can manage their energy costs and train residents to conserve energy. In addition to organizing and making presentations at these sessions, Rebuild America also extensively updated written information on these subjects that was included in the conference notebooks. The Chicago Housing Authority presented case studies of its activity at each of these sessions as well.

\section{NAHRO Conferences and Meetings}

The National Association of Housing and Redevelopment Officials (NAHRO) is a strategic partner of Rebuild America. Rebuild America uses this partnership extensively to make energy presentations to housing authorities and to identify potential housing authority partners. Energy sessions were organized and presented at each National Conference from 2000 to 2002 and at several regional conferences.

\section{Energy Performance- Contracting Workshop}

In 2001 and 2002, Rebuild America cosponsored a week-long training workshop on energy performance contracting in public housing with the Illinois Office of HUD and two Rebuild America Strategic Partners: NAHRO and the National Association of Energy Service Companies (NAESCO). Similar workshops were provided in 1999 and 2000. This is the only training class of its kind available to housing authorities as well as to HUD officials that teaches the details of performance contracting and the nuances of adhering to HUD regulations while following the performance-contracting process.

Attendance at this workshop increased each of the past 2 years, exceeding capacity in 2002. In 2001, the workshop was attended by 43 people -23 housing authority staff members representing 20 different authorities, 12 energy service company employees from 9 different companies, 6 HUD staff from 6 different field offices, and 2 people not associated with public housing. In 2002, 47 people attended the workshop-35 housing authority staff members representing 25 different housing authorities, 7 energy service company employees representing 4 different companies, and 5 HUD staff. 
Table 5. Conferences, workshops, and training

HUD'S OFFICE OF PUBLIC AND INDIAN HOUSING EVENTS

Resident Leader Training Conference, Dallas, Texas, April 2001

2001 PHA Staff Training Conference, Washington, DC, August 2001

\section{NATIONAL ASSOCIATION OF HOUSING AND REDEVELOPMENT OFFICIALS (NAHRO) EVENTS}

National Conference, Phoenix, Arizona, November 2000

North Central Regional Conference/Ohio Housing Authority Conference, Cleveland, Ohio, April 2001

Mid-Atlantic Regional Conference, Pittsburgh, Pennsylvania, April 2001

Pacific-Northwest Regional Conference, Seattle, Washington, April 2001

Pacific Southwest Region Meeting of the Development, Modernization, and Maintenance Officers, Santa Clara, California, May 2001

Southeast Regional Conference, Ft. Lauderdale, Florida, July 2001

Pacific Southwest Region Meeting of the Development, Modernization, and Maintenance Officers, Reno, Nevada, September 2001

National Conference, Nashville, Tennessee, October 2001

Southeast Regional Conference, Asheville, North Carolina, November 2001

National Conference, Seattle, Washington, October 2002

\section{OTHER EVENTS OF HOUSING ORGANIZATIONS}

New Hampshire State Directors Association Meeting, Concord, New Hampshire, April 2001

Missouri State Directors Association Meeting, Sedalia, Missouri, May 2001

Public Housing Authority Directors Association (PHADA) Annual Convention, Portland, Oregon, May 2001

National Low-Income Energy Conference, Cincinnati, Ohio, June 2001

Affordable Comfort Conference, Cincinnati, Ohio, April 2002

National Multifamily Building Efficiency Conference, New York City, New York, June 2003

\section{REBUILD AMERICA EVENTS}

National Forum, Atlanta, Georgia, March 2001

Energy Performance Contracting Workshop for Public Housing Authorities, Chicago, Illinois, June 2001

Energy Performance Contracting Workshop for Public Housing Authorities, Chicago, Illinois, June 2002

National Forum, New Orleans, Louisiana, July 2002

Effective Approaches to Improving Energy Efficiency in Public Housing, Canton, Ohio, September 2002

An analysis of 1999-2001 workshop participants indicated that 20 of the 33 housing authorities represented at these workshops have issued an RFQ to initiate implementation of a performance contract. Over the 4 years, HUD staff from 11 different field offices have received training.

Information compiled for the 2002 workshop revealed just how important housing authorities view performance contracting as a means to energy efficiency. Unofficially through 2002, 55 housing authorities have energy performance contracts that are in the repayment phase, 28 have projects in construction, 24 have investment-grade audits being performed, and 27 are in the process of selecting an energy service company. Based on a study cofunded by Rebuild America (Goldman et al. 2002) that examined market trends in the U.S. energy service company industry, the median project cost for 39 public 
housing performance contracts was about $\$ 2$ million, and the median benefit-to-cost ratio for 31 of these projects was 1.5 (assuming a 7\% discount rate). Information compiled internally by HUD in 2001 on the use of HUD's energy incentives by public housing authorities is consistent with this analysis. Based on 51 completed projects, total project cost was estimated to be \$99 million, and annual energy savings was estimated to be $\$ 14.8$ million (based on preproject engineering estimates).

\section{Affordable Comfort's High- Performance Public Housing Workshop}

Rebuild America worked with HUD's Healthy Homes Program and others to sponsor a fullday workshop at the 2002 Affordable Comfort Conference on high-performance public housing. The workshop brought together 50 people from around the United States to address issues of healthy and energy-efficient public housing, and the relationship of health issues and energy-efficiency conditions and improvements. The participants in the workshop included HUD officials, public housing residents and managers, public health specialists, and energy researchers and practitioners.

The goal of the workshop was to discuss the areas of highest concern in creating healthy environments and to identify the steps needed to realize them. The workshop focused on the specifics of health and safety in public housing in four key areas:

- resident health and safety standards,

- operations and maintenance,

- major renovations, retrofits, and energy upgrades, and

- new construction.

Breakout groups on each of these topics explored the major health and safety issues that should be addressed and considered whether current regulations and practices support or inhibit the ability of residents and owners to address these issues. The groups made procedure and policy recommendations to improve the health and safety of public housing residents while increasing building performance. Ideas generated include

- establishing resident's rights and responsibilities for resident health;

- reintegrating maintenance with building owners and residents to improve education and accountability;

- performing comprehensive health and energy assessments using standardized audits and teams composed of public health officials, residents, and maintenance staff; and

- incorporating health-related measures in retrofit and new projects by holding design charrettes and specifying measurable performance goals.

Because of the success of this initial workshop, a follow-up workshop is planned for the 2003 Affordable Comfort Conference. 


\section{Assistance to the Office of Public and Indian Housing}

As part of its work under the IAA, Rebuild America provided support to HUD PIH in a number of areas. Rebuild America reviewed the HUD Energy Efficiency Action Plan during its development to determine its effect on PIH. Rebuild America also discussed the action plan recommendations with the authors of the document.

Rebuild America assisted PIH in the initial planning for a future PIH-sponsored energy conference by identifying and reviewing possible training topics and developing a list of potential presenters and case studies. Rebuild America partnerships will probably present information and their successful case studies at this conference.

Rebuild America also assisted PIH in drafting a PIH Notice on HUD's additional operating subsidy and frozen-base energy incentives. Rebuild America extensively reviewed and provided rewrites of three drafts of this notice. 


\section{Conclusions and Recommendations}

Results from the HUD-DOE IAA exceeded all goals relative to partnership formation, project development, and education and training. The work performed under the IAA demonstrates that energy efficiency projects can be successfully implemented, lowering utility costs in public housing. The IAA also showed that DOE programs, in particular the Rebuild America and Weatherization Assistance Programs, offer natural linkages and opportunities to work with public housing authorities.

Several major actions are needed to continue the efforts started under the IAA and achieve the energy goals desired by HUD.

- The successes achieved under the IAA and by others need to be thoughtfully documented and effectively communicated in order to improve energy education and increase action within housing authorities. Too many excellent solutions to energy opportunities are not being duplicated within the public housing authority community and are not being encouraged by HUD field offices. Case studies and standardized materials should be developed to share among housing authorities. Training formats that reach housing authorities as well as HUD staff need to be formulated, and a means of achieving peer-to-peer education needs to be established.

- Existing Rebuild America partnerships with public housing authorities and associated organizations need continued support. Additional partnerships focusing on key energy approaches that HUD wants to feature and promote should be developed to help make these approaches mainstream within the public housing authority community. These approaches include aggregation of small- and mediumsized housing authorities for energy audits, energy management, bulk purchases, fuel purchases, and performance contracting; collaborations with the DOE Weatherization Assistance Program; use of ENERGY STAR equipment and programs; and inclusion of energy efficiency in HOPE VI projects. Partnerships that transfer lessons learned from public housing to Indian housing should also be developed.

- A focus group needs to be convened to help streamline the performancecontracting process for public housing authorities. All principal parties—large, medium, and small housing authorities; energy service companies; HUD Field Office and Headquarter staff; consultants; housing authority associations; and energy service company associations-should be represented.

- An ongoing assessment of performance contracting should be initiated to verify and document past performance, monitor the activity, and guide future efforts. This assessment should build upon three previous studies: the market trend analysis (cofunded by Rebuild America) of the U.S. energy service company industry that included public housing (Goldman et al. 2002); an internal, unpublished survey performed by HUD in 2001 that gathered information about housing authorities' use of HUD's energy incentives; and Rebuild America's tally of the number and names of housing authorities and energy service companies involved in performance 
contracting using information gathered from participating energy service companies. A comprehensive evaluation that builds upon these previous studies could accurately tally the extent of performance-contracting activity in public housing and across the HUD Field Offices. Such a comprehensive study would verify the savings and economics achieved in complete and current projects, identify failures and reasons for nonperformance, assemble lists of waivers and other standard practices associated with performance contracting, and identify the key characteristics of projects that lead to the successful implementation of performance contracting.

- Methods of encouraging HOPE VI award winners to achieve energy-efficient designs should be formulated, and the means by which housing authorities can achieve energy-efficient designs should be developed. Ideas include mandatory attendance at an energy training class by all HOPE VI award winners, use of the ENERGY STAR and DOE Building America Programs, energy design charrettes, and peer-to-peer education by housing authorities that previously achieved efficient energy designs. An evaluation of HOPE VI projects that examines the design process, quality indicators, and energy use should also be performed.

- Methods need to be developed to allow HUD to better manage its public housing energy program. An energy database would allow housing authorities and HUD to determine savings potential, set goals, track progress, and allocate resources. A benchmarking tool focusing on the public housing stock would allow HUD and housing authorities to make comparative analyses. 


\section{References}

Brinch, Jeannette. 1996. DOE-HUD Initiative on Energy Efficiency in Housing:A Federal Partnership. ORNL/SUB/93SM840V, Oak Ridge National Laboratory, Oak Ridge, Tenn., June 1.

Goldman, Charles A., Julie G. Osborn, Nicole C. Hopper, and Terry E. Singer. 2002.

Market Trends in the U.S. ESCO Industry: Results from the NAESCO Database Project. LBNL-49601, Lawrence Berkeley National Laboratory, Berkeley, Calif., May (see http://eetd.lbl.gov/ea/EMS/ EMS_pubs.html).

HUD. 1999. Five Year Plan for Energy Efficiency: 1999 Report to Congress. U.S. Department of Housing and Urban
Development (see www.hud.gov:80/ offices/cpd/energyenviron/energy/ lawsandregs/fiveyrplan.cfm).

HUD. 1995. Report on Review of Opportunities to Reduce Utility Costs at Public Housing Authorities. 95-SE-1010001, U.S. Department of Housing and Urban Development, Office of the Inspector General, Office of Audit, Northwest/Alaska, Seattle, Washington, May 31.

HUD. 2000. Energy Desk Book for HUD Programs. U.S. Department of Housing and Urban Development, April (see www.huduser.org/publications/destech/ene rgybook.html). 


\section{Appendix A: Summary of Public Housing Partnership Activity}

This appendix provides a narrative of the projects performed by each partnership participating in the IAA and the assistance provided by Rebuild America. Table A.1 provided at the end of Appendix A summarizes the activity performed by each partnership and categorizes the activity by the type of financing involved, actions taken, and technology areas involved. Partnerships are reported by three sections: (1) new housing authority partnerships established during the IAA, (2) new partnerships with organizations affiliated with public housing authorities and established during the IAA, and (3) existing Rebuild America public housing authority partnerships that initiated new projects during the IAA and were supported by this effort.

\section{Housing Authority Partners Added under the IAA}

\section{Akron Metropolitan Housing Authority, Ohio}

The Akron Metropolitan Housing Authority joined Rebuild America in January 2002. Starting in 2002, it purchased 2000 energyefficient refrigerators through the Consortium for Energy Efficiency's (CEE's) bulk purchasing program to replace existing units as they fail. It is currently purchasing 3000 additional units which will be replaced at one time as an energy retrofit using HUD's additional operating subsidy energy incentive to fund the purchase. It is also investigating the use of an energy performance contract to implement other energy and water conservation measures.
Rebuild America provided the authority with information on performance contracting and performance-contracting workshop notebooks. Rebuild America also linked the authority to the utility purchasing group organized by Stark Metropolitan Housing Authority to facilitate a lower cost for natural gas.

\section{Albany Housing Authority, New York \\ The Albany Housing Authority joined Rebuild America in January 2002. It is conducting an energy audit with assistance from NYSERDA on a 250-unit, low-income building and/or a 160-unit high-rise for senior citizens. It is also serving as a NYSERDA demonstration site for an innovative stairwell lighting system, one feature of which is that the lights turn off or dim when nobody is present.}

Rebuild America linked the housing authority to NYSERDA's Assisted Multifamily Program that helps incorporate energy efficiency into practices as well as buildings. The NYSERDA program helped arrange the energy audits and also brought the housing authority into the lighting demonstration project because the housing authority was in one of NYSERDA's energy target zones.

\section{Albuquerque, New Mexico}

The Albuquerque Housing Authority joined Rebuild America in November 2000. The city of Albuquerque, which operates the public housing, initiated a performance contract to perform energy and water conservation measures. The RFQ was issued in April 2002, and the Energy Audit Agreement was implemented in December 2002. 
Rebuild America reviewed preliminary drafts of the performance-contracting RFQ and the Energy Audit Agreement and provided the authority with performance-contracting workshop notebooks.

\section{Annapolis Housing Authority, Maryland}

The Annapolis Housing Authority joined Rebuild America in May 2002. It is primarily interested in bulk purchasing agreements to replace refrigerators and toilets using the HUD additional operating subsidy energy incentive to fund the purchase. It was also interested in purchasing natural gas and electricity on the wholesale market and using the HUD ratereduction energy incentive with its current gas contract to retain a portion of the savings within the housing authority. It wanted to determine the feasibility of repairing an existing solar domestic water system, install lighting retrofits in its high-rise and administration buildings, and use checkmetering systems. However, these projects are inactive because the champion of these efforts, the authority's Director of Maintenance and Modernization, left to work at another housing authority.

Rebuild America helped the housing authority develop its gas purchase RFP in June 2001.

\section{Berlin Housing Authority, New Hampshire}

The Berlin Housing Authority joined Rebuild America in March 2001. It performed an energy audit and purchased refrigerators with the help of the state of New Hampshire.

Rebuild America linked the housing authority to the state of New Hampshire to gain the state's assistance.

\section{Binghamton Housing Authority, New York}

The Binghamton Housing Authority is replacing heating systems in its row houses as part of an integrated operating and maintenance/design process. It is doing this project with assistance from NYSERDA, who will use this case study to determine the feasibility of such an approach.

Rebuild America linked the housing authority to NYSERDA's Assisted Multifamily Program that helps incorporate energy efficiency into practices and buildings.

\section{Buffalo Municipal Housing Authority, New York}

The Buffalo Municipal Housing Authority is renovating houses through a "Buy HUD Dollar Homes" program, and it wants to teach job skills to public housing residents as part of the renovation.

Rebuild America provided the housing authority with information on a HUD ROSS grant to help fund the job skills training. Through Rebuild America, the Buffalo Municipal Housing Authority is linked with the Chicago and Tallahassee Housing Authorities who are implementing similar energy-related job skill training programs.

\section{Cumberland Housing Authority, Maryland}

The Cumberland Housing Authority joined Rebuild America in June 2001. It completed a simple energy audit (5-year type) of all its housing units, installed low-flow pressureassisted toilets in one 100-unit high rise for the elderly, and reviewed options for the purchase and installation of energy-efficient refrigerators. The housing authority is currently analyzing options for fixing or replacing a central boiler system in its JFK high-rise building for the elderly to increase efficiency.

Rebuild America helped inspect the central boiler system in the JFK high-rise building, reviewed the building's energy bills, and 
provided recommendations concerning the possible repair or replacement of the boiler.

\section{Gastonia Housing Authority, North Carolina}

The Gastonia Housing Authority joined Rebuild America in February 2002. It is currently working with a local DOE Weatherization Assistance Program agency. It screened its utility bills to verify potential savings under a performance contract and is currently investigating how and when to proceed with performance contracting. The housing authority is also currently investigating options for financing energy retrofits in its tenant-based, Section-8 housing.

Rebuild America helped the housing authority conduct a regulatory review and drafted a sample waiver request for use in a future performance contract.

\section{Hagerstown Housing Authority, Maryland}

Hagerstown Housing Authority joined Rebuild America in April 2001. It negotiated a new gas contract for November 2001-2002. For the past several years it has purchased gas on the open market and used HUD's rate-reduction energy incentive to retain some of these savings within the housing authority. It is incorporating energy efficiency design into its \$27 million HOPE VI project. The housing authority is also currently reviewing options for the installation of energy-efficient refrigerators at time of replacement (it replaces about $10 \%$ of its refrigerators per year) and determining the feasibility of repairing an existing solar heating system.

Rebuild America performed energy modeling and provided recommendations on the housing authority's HOPE VI project to make it more energy efficient.

\section{Houston Housing Authority, Texas}

The Houston Housing Authority is implementing a performance contract (currently at the audit stage) to install energyefficiency improvements.

\section{Kansas City Housing Authority, Missouri}

The Kansas City Housing Authority is interested in performing an energy audit of all of its public housing properties. It is working with the local DOE Weatherization Assistance Program agency to have wall insulation installed in units that were previously renovated but without significant energy improvements. It is also training residents in job skills related to energy, and demonstrating advanced equipment technologies.

Rebuild America linked the housing authority to a DOE research program interested in field testing heat pump water heaters as a possible advanced technology it may want to demonstrate.

\section{Keene Housing Authority, New Hampshire}

The Keene Housing Authority joined Rebuild America in July 2002. It is collaborating with the Somersworth Housing Authority and the Town of Lebanon Housing Authority to implement a performance contract. They issued their RFQ in May 2002.

Rebuild America brought these three housing authorities together, guided them through the aggregation process, provided them with the performance-contracting workshop materials, and assisted them in developing the joint RFQ.

\section{Lucas Metropolitan Housing Authority, Ohio}

The Lucas Metropolitan Housing Authority is investigating the use of performance 
contracting to implement energy conservation measures.

Housing authority staff attended the performance-contracting training workshop offered by Rebuild America in June 2002.

\section{Meriden Housing Authority, Connecticut}

The Meriden Housing Authority is implementing a performance contract to install energy conservation measures. The audit was performed in April 2002.

Rebuild America provided assistance during the RFQ stage of the performance contract.

\section{Miami-Dade Housing Agency, Florida}

The Miami-Dade Housing Agency is building energy-efficient, sustainable housing under its HOPE VI project. It also wants to include an energy education component to the orientation sessions to be given to new occupants and establish an approach to helping occupants with high energy and water bills.

The DOE Atlanta Regional Office cosponsored a sustainable design charrette for the housing authority's HOPE VI project in December 2001 to promote energy-efficient design. Funding support for the charrette was provided through DOE's Communities Initiative. Rebuild America staff from Oak Ridge National Laboratory and DOE and staff from the Florida Solar Energy Center (DOE Building America Program) participated in the building science team to provide advice on energy-related design, implementation, and education. A staff person from Lithonia Lighting (a Rebuild America Business Partner) served on the site planning team to provide technical information on security lighting issues. DOE also provided funds to the Miami-Dade County Department of Environmental Resources Management for the development of two videos documenting the
HOPE VI development and construction process.

\section{Newark Housing Authority, New Jersey}

The Newark Housing Authority joined Rebuild America in October 1999. It completed an authority-wide energy audit, with the state of New Jersey performing the audit of its administration buildings. The housing authority is implementing a performance contract to install energy and water conservation measures.

Housing authority staff attended the 2002 performance-contracting training workshop offered by Rebuild America. Rebuild America also provided it with performance-contracting workshop materials and reviewed its RFQ.

\section{Newport News Redevelopment and Housing Authority, Virginia}

The Newport News Redevelopment and Housing Authority joined Rebuild America in April 2001. It is initiating a performance contract to install energy and water conservation measures and possibly repair its main gas lines.

Housing authority staff attended the performance-contracting training workshop offered by Rebuild America in June 2001. Rebuild America also reviewed its performance-contracting RFQ in August 2001.

\section{Niagara Falls Housing Authority, New York}

The Niagara Falls Housing Authority is implementing a performance contract with Viron Energy Services (a Rebuild America business partner) to install energy conservation measures. The project is currently in the construction phase. 


\section{Oakland Housing Authority, California}

The Oakland Housing Authority joined Rebuild America in September 2001 and was Rebuild America's Partnership of the Year in 2002. Since about 1994, it has used a utilitytracking program to monitor its utility consumption and costs. It completed an energy performance contract and partnered with its local water utility for on-site training concerning landscape irrigation. It installed ENERGY STAR washers and dryers in common areas of 18 locations and a "cool roof" and ENERGY STAR air conditioners in an administrative building. Starting in July 2002, it has been implementing EPA's "Sleep is Good" monitor in their power management program.

The housing authority is currently implementing a HOPE VI project involving about 600 housing units (105 of which are for home ownership). It is piloting a "Read This" series of articles paid for by HUD's Healthy Home Program and revised for public housing. Through in-house staff, it is planning to demolish and replace its headquarter building, replace roofs on seven buildings, demolish and rebuild an eight-unit apartment building, and rehabilitate a fourteen-unit apartment building.

Rebuild America provided design review and specifications for the housing authority's new and rehab projects, with emphasis on mold and moisture issues, and helped it develop a prototype for renovating smaller, scattered site housing.

\section{Panama City Housing Authority, Florida}

The Panama City Housing Authority joined Rebuild America in August 2001. It is implementing energy conservation measures, such as new windows and attic insulation, using the housing authority's operating and capital funds to reduce the utility burden on the residents and to improve occupancy rates. It is also installing air conditioners in housing to improve comfort and marketability and a solar sun tube to provide natural lighting in its office building.

Rebuild America linked the housing authority with a state of Florida program to perform energy audits. The housing authority installed modular through-the-wall air conditioners to address its cooling needs and the sun tubes on the basis of recommendations provided by the state program.

\section{Rahway Housing Authority, New Jersey}

The Rahway Housing Authority joined Rebuild America in April 2001. It is initiating a performance contract to install energy and water conservation measures.

Housing authority staff attended the performance-contracting training workshop offered by Rebuild America in June 2001.

\section{Rockford Housing Authority, Illinois}

The Rockford Housing Authority is implementing a performance contract to install energy and water conservation measures. Construction on the project is currently under way.

Housing authority staff attended the 1999 and 2000 performance-contracting training workshops offered by Rebuild America.

\section{San Antonio Public Housing Authority, Texas}

The San Antonio Public Housing Authority joined Rebuild America in March 2001. It is initiating a performance contract to install energy and water conservation measures. The audit is currently being performed.

Rebuild America provided a half-day discussion to housing authority staff on the 
performance-contracting process and roles following its issuance of a performancecontracting RFP.

\section{Somersworth Housing Authority, New Hampshire}

The Somersworth Housing Authority joined Rebuild America in January 2001. It is collaborating with the Keene Housing Authority and the Town of Lebanon Housing Authority to implement a performance contract. It issued an RFQ in May 2002.

Rebuild America brought these three housing authorities together, guided them through the aggregation process, provided them with the performance-contracting workshop materials, and assisted them in developing the joint RFQ.

\section{Springfield Housing Authority, Missouri}

The Springfield Housing Authority joined Rebuild America in April 2001. It is interested in retrofitting or replacing the mechanical systems in four aging high-rise buildings.

Rebuild America inspected the mechanical systems in the four buildings and provided recommendations concerning the upgrade of these systems.

\section{Tacoma Housing Authority, Washington}

The Tacoma Housing Authority joined Rebuild America in June 2001. It is interested in a zero (very low) impact green development for its HOPE VI project. Retaining storm water discharge on site as much as possible is a primary issue. An A\&E was hired, and community design charrettes were held.

Rebuild America assisted the housing authority by providing it with a summary of the HOPE VI activity ongoing with the Hagerstown Housing Authority and MiamiDade Housing Agency.

\section{Tallahassee Housing Authority, Florida}

The Tallahassee Housing Authority joined Rebuild America in January 2002. It completed a performance contract in 2001. Beginning in January 2002, the energy service company, as part of this performance contract, developed and implemented an energy education program to assist public housing occupants with high energy bills using several residents as the trainers/auditors. The housing authority is also interested in extending this program to its Section 8 tenants.

Rebuild America reviewed course material for the energy education program, provided recommendations on program implementation, and provided several watt-hour and temperature measuring devices for use by the trainers/auditors. Following an initial 2-day training session in January 2002, Rebuild America worked with the two resident trainers/auditors in the field for 2 days implementing what they had learned in the training course.

\section{Troy Housing Authority, New York}

The Troy Housing Authority is incorporating energy efficiency practices into its buildings with assistance from NYSERDA.

Rebuild America linked the housing authority to NYSERDA's Assisted Multifamily Program that helps incorporate energy efficiency into practices as well as buildings.

\section{Virgin Island Housing Authority}

The Virgin Island Housing Authority is initiating a performance contract to install energy and water conservation measures.

Housing authority staff attended the 2002 performance-contracting training workshop offered by Rebuild America. Rebuild America also reviewed the housing authority's draft RFQ to select an energy service company. 


\section{Wilson Housing Authority, North Carolina}

The Wilson Housing Authority joined Rebuild America in May 2001. It completed an investment-grade audit. Currently it is working with the utility to convert all master utility meters to automated individual meters, and it is planning to install measures identified from the audit (especially space- and waterheating combination units), perhaps through an energy performance contract.

Rebuild America assisted the housing authority in writing an RFQ and reviewing proposals for the investment-grade energy audit. Rebuild America also accompanied housing authority staff in meetings with the municipal utility to discuss metering issues. Housing authority staff attended the 2001 performance-contracting training workshop offered by Rebuild America.

\section{Non-Housing Authority Partners Added under the IAA}

\section{New York State Energy Research and Development Authority (NYSERDA)}

NYSERDA joined Rebuild America in 1996. It is working with the Buffalo HUD Office to develop a streamlined process for housing authorities to use NYSERDA funds and programs and keep at least a portion of the energy savings.

\section{Non-Profit Housing Association of Northern California, California}

The Non-Profit Housing Association of Northern California joined Rebuild America in June 2001. It is interested in bringing together developers, architects, finance companies, and housing authorities to boost energy efficiency in low-income housing by providing energy-efficiency education and training and by finding new or existing resources to retrofit existing buildings and integrate energy-efficiency into new buildings.

\section{Pacific Southwest Regional Alliance, California and Nevada}

The Pacific Southwest Regional Alliance is composed of 50 housing authorities from the states of California and Nevada and operates under the auspices of NAHRO. Development, modernization, and maintenance officers from these housing authorities meet regularly, and they are interested in utility accounting software and energy performance contracting.

Rebuild America participated in meetings where performance contracting and photovoltaic systems were discussed and presentations were made by two energy service companies.

\section{Seattle Regional Office, Washington}

DOE's Seattle Regional Office and the Washington HUD Office of Public Housing initiated a cooperative pilot project to develop an aggregated, standardized procurement process for conducting energy audits and performing engineering-based utility allowance calculations. Housing authorities, particularly small authorities because of their limited internal capacity in energy conservation, often procure energy audits that provide limited guidance for capital planning and utility management. Utility allowances are usually calculated using average historical consumption, which captures and rewards inefficient energy management and operations, rather than using engineering-based allowances which motivate residents to conserve by setting reasonable consumption levels.

The pilot will demonstrate how housing authorities in Washington, Oregon, and Idaho can receive accurate, detailed audits and utility allowance calculations by aggregating their 
procurement and developing thorough RFP documents. Coupling the audits with utility allowance calculations will provide a lower overall cost and higher quality utility allowance calculation than if procured separately.

A second pilot will also be performed to develop a standardized procurement process for purchasing utility-tracking software. This software will simplify utility reporting under the HUD Performance Funding System and allow a housing authority to better manage its utility costs. Use of standardized utilitytracking software by housing authorities in a state or region will allow HUD or others to aggregate utility data and focus technical assistance and training on those authorities with the highest consumption or energy intensity. This pilot will also use the utility data to explore methods for better representing utilities in the PIC database and PHAS financial indicators. Standardization of physical data from the detailed energy audits performed in the first pilot will allow accurate estimates to be made of performance baselines and tools to be developed for measuring progress in reducing energy usage.

\section{State of Colorado}

The state of Colorado's Office of Energy Management and Conservation operates the Rebuild Colorado Program. It is initiating efforts to focus attention on the state's public housing authorities (both public housing and subsidized housing) to help authorities identify and assess energy-saving projects in buildings, with special emphasis on helping authorities implement energy performance contracts and collaborations with the state's Weatherization Assistance Program.
Rebuild Colorado assisted the Boulder Housing Authority in its public housing energy performance contract by providing a technical review of the energy service company's audit results and is currently helping the authority reformulate the project because of uncertainties found in the audit results. Rebuild Colorado is also currently working with the Jefferson County and Aurora Housing Authorities by performing a preliminary assessment of their housing portfolios to identify energy savings potential and the applicability of energy performance contracting and weatherization. Previously, the Jefferson County Housing Authority had teamed with the county's weatherization agency to weatherize all of its scattered-site public housing.

Rebuild America assisted Rebuild Colorado by helping define state offerings and by getting a representative to attend the 2002 public housing conference sponsored by Stark Metropolitan Housing Authority to learn more about housing authorities, what motivates them, and energy options in public housing. Rebuild America also served as a technical resource during initial meetings between Rebuild Colorado and these three housing authorities and the local HUD Office.

\section{State of Louisiana}

The state of Louisiana's Department of Natural Resources created a revolving loan fund backed by state-issued bonds for energy conservation projects. Five housing authorities have requested loans under the energy fund to implement energy performance contracts.

Rebuild America assisted the state with defining the concept of a loan fund and helped identify implementation approaches. 


\section{Existing Housing Authority Partners with New Projects}

\section{Asheville Housing Authority, North Carolina}

The Asheville Housing Authority joined Rebuild America in September 1997. Before the IAA, in May 1999, it incorporated a number of energy measures during the rehab of a 100-unit multifamily building (McCormick Heights, formerly Mountainside Apartments) that reduced energy use by about $30 \%$. Measures that were installed include energy-efficient windows and doors, heat pumps, efficient lighting, energy-efficient appliances, and water fixtures. Carolina Power and Light assisted on ductwork design, and weatherization services were provided by the local Weatherization Assistance Program agency.

During the IAA, it issued an RFQ for a performance contract to install energy conservation measures, but it is now considering how to be its own energy service company.

Housing authority staff attended the performance-contracting training workshop offered by Rebuild America in June 2001.

\section{Austin Housing Authority, Texas}

The Austin Housing Authority is part of Rebuild Austin, which joined Rebuild America in August 1998. The housing authority is implementing a performance contract to install energy and water conservation measures. It is currently in the construction phase.

Housing authority staff attended the 2002 performance-contracting training workshop offered by Rebuild America.

\section{Boston Housing Authority, Massachusetts}

The Boston Housing Authority is part of the Rebuild Boston Energy Initiative, which joined Rebuild America in May 1995. The housing authority was Rebuild America's Public and Affordable Housing Partnership of the Year in 2001. Before the IAA, it implemented an energy performance contract in one of its federally funded public housing developments (Phase I). Construction of this project was completed in 2001 - a central steam plant was replaced with distributed gasfired, hydronic boilers, and water conservation measures were installed.

During the IAA, the housing authority partnered with its local utilities and others to develop an energy and water efficiency master plan for the authority's properties. It is currently working with three schools of public health and others to investigate health issues in public housing and the impact of energyrelated projects on health concerns. It is also working toward making the design of a HOPE VI project energy efficient and initiating additional performance contracts (Phase II and others) to install energy and water conservation measures in other housing developments.

Rebuild America assisted the housing authority in implementing its performance contracts by reviewing the RFQs for both Phases I and II. Housing authority staff also attended the 2001 performance-contracting training workshop offered by Rebuild America. Rebuild America performed a computer simulation to ensure that wall system moisture problems would not result following a retrofit project. Rebuild America conducted an analysis of additional operating subsidy energy incentive financing. Rebuild America also assisted in drafting a letter to the local HUD field office regarding the use of capital funds for internal borrowing under 
additional operating subsidy energy incentive projects.

\section{Chicago Housing Authority, Illinois}

The Chicago Housing Authority joined Rebuild America in July 1996. Before the IAA, it purchased wholesale natural gas and used HUD's rate-reduction energy incentive to keep half of the costs savings within the housing authority. It entered into a $\$ 15$ million performance contract in December 1997 (Phase I) to install over 10,000 energyefficient refrigerators, improve common area lighting in 58 facilities, convert a mechanical heating plant at a high-rise facility, decentralize a heating system, and install water measures at a low-rise development. The housing authority organized a training workshop for its power plant engineers on energy-efficient operation and maintenance techniques. It also trained and developed a resident-owned weatherization company that received funding from the local Weatherization Assistance Program to perform weatherization tasks on low-income housing.

During the IAA, the housing authority negotiated a lower electric rate with the local utility and used HUD's rate-reduction energy incentive to keep half of the cost savings within the authority. As part of the negotiations, the electric utility also provided some grant funds. It worked with DOE to demonstrate a new vandal-resistant lighting fixture design. It assessed the condition of the underground steam distribution system at Lathrop Homes to determine how to approach the maintenance and repair of this system. It also won a HUD ROSS grant to train a second group of residents in weatherization skills and to help them form a resident business. The housing authority is currently implementing a Phase II performance contract to install energy and water conservation measures in other buildings.
Rebuild America assisted the housing authority in some aspects of implementing its performance contract. Staff members attended the 2002 performance-contracting training workshop offered by Rebuild America. Rebuild America helped provide the training to the housing authority's power plant engineers and assisted the housing authority in providing the technical training for the resident weatherization program. Rebuild America linked the housing authority to another DOE-funded program that developed and tested vandal-resistant lighting fixtures in several housing authority properties. Rebuild America funded the U.S. Army Cold Regions and Engineering Research Laboratory to diagnose the steam distribution system at Lathrop Homes and provide guidance on how to approach its maintenance and repair.

\section{District of Columbia Housing Authority, District of Columbia}

The District of Columbia Housing Authority joined Rebuild America in July 1999. During the IAA, the housing authority developed an energy and environmental master plan. In developing the master plan and bringing the utility billing system in-house, it checked its utility bill's accuracy and found $\$ 2$ million in savings from billing errors, overpayments, and paying for facilities that didn't belong to the housing authority. It is initiating a performance contract to install energy and water conservation measures and is interested in purchasing wholesale natural gas and electricity.

Rebuild America provided the housing authority with performance-contracting workshop materials and information about how other Rebuild America housing authority partners purchase utilities on the wholesale market. 


\section{Stark Metropolitan Housing Authority, Ohio}

The Stark Metropolitan Housing Authority joined Rebuild America in April 1997, winning Rebuild America's 1999 Energy Champion Award for Excellence in Public Housing and the state of Ohio's 2000 Governor's Award for Energy Excellence. Before the IAA, it completed an energy audit of its 2700 housing units. It implemented a major energy-efficiency improvement project using HUD's additional operating subsidy energy incentive and performing the work itself. In this project, the housing authority replaced electric baseboard heaters with gasfired furnaces in 99 scattered-site public housing. The $\$ 500,000$ project cost the housing authority and HUD only $\$ 105,000$, saving $\$ 181,000$ per year with a simple payback period of 0.8 years.

During the IAA, the housing authority completed two major energy efficiency projects. The first project at Cherrie Turner Towers (formerly Metropolitan Arms) was initiated in 1999 and dedicated in October 2001. The project converted efficiency apartments to one-bedroom units and installed energy-efficient refrigerators, new geothermal heat pumps to replace old electric baseboards and provide air conditioning (previously supplied in only some units by tenant-owned window units), water-conserving toilets, additional insulation, energy-efficient doors and windows, compact flourescent lighting, and energy-efficient (ENERGY STAR) appliances. This project was financed in part using HUD's additional operating subsidy energy incentive. In the second project, the authority performed a complete energy upgrade of Jackson Sherrick using
Comprehensive Grant funds-refrigerators, doors, furnaces, windows, water heaters, toilets, and heat pumps to provide air conditioning. The housing authority performed an authority-wide appliance upgrade, replacing 2000 refrigerators using HUD's additional operating subsidy energy incentive and replacing electric stoves with gas models. The authority organized a purchasing group with six other Ohio housing authorities (Lucas, Loraine, Zanesville, Portage, Jefferson, and Harrison Metropolitan Housing Authorities) to purchase natural gas at below market rate and to take advantage of HUD's rate-reduction energy incentive to keep half of the cost savings within the housing authorities. The first annual contract was signed in June 2001 and averaged about $12 \%$ below market rate. The housing authority also helped sponsor two conferences that brought together housing authorities within the state of Ohio to discuss energy opportunities and solutionsone in November 1999 and another in September 2002.

Stark Metropolitan Housing Authority is currently interested in using and demonstrating the applicability of several advanced energy technologies, including heat pump water heaters, microturbines, fuel cells, and solar.

Rebuild America, through the Ohio Department of Development, provided a $\$ 50,000$ grant to help finance the cost of the energy audit. Rebuild America participated in both conferences sponsored by the housing authority, and linked it with a DOE program interested in demonstrating heat pump water heaters. 


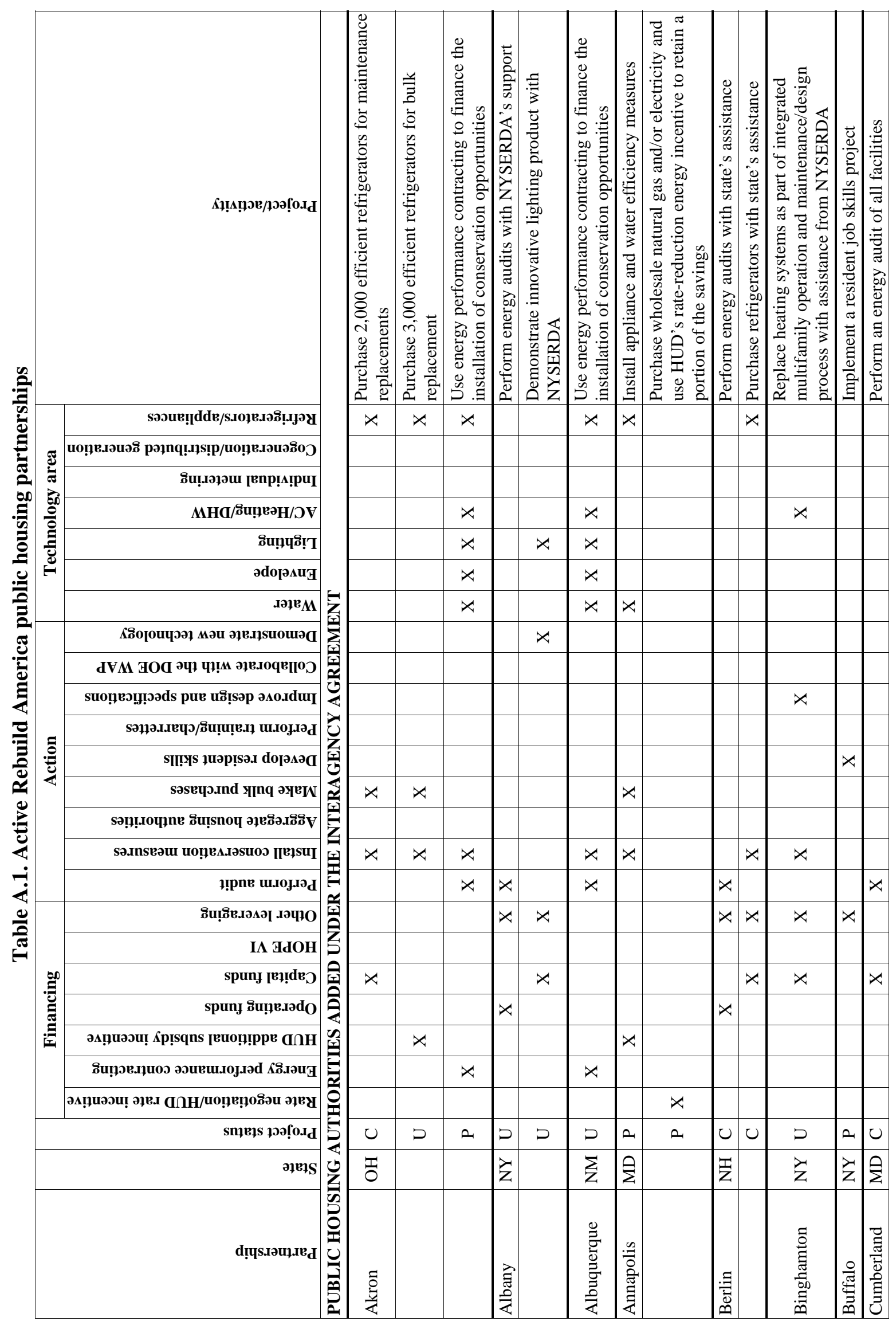









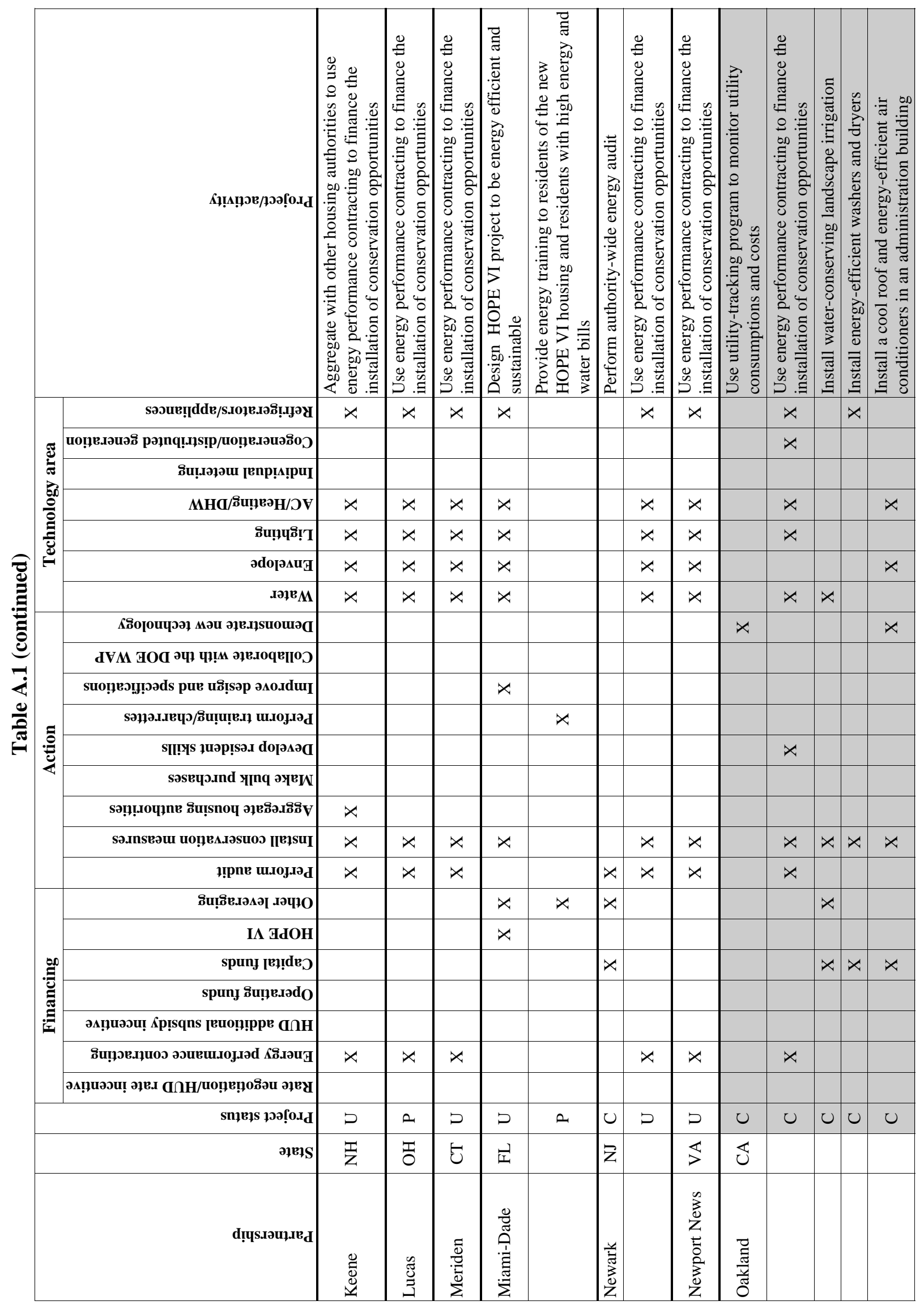




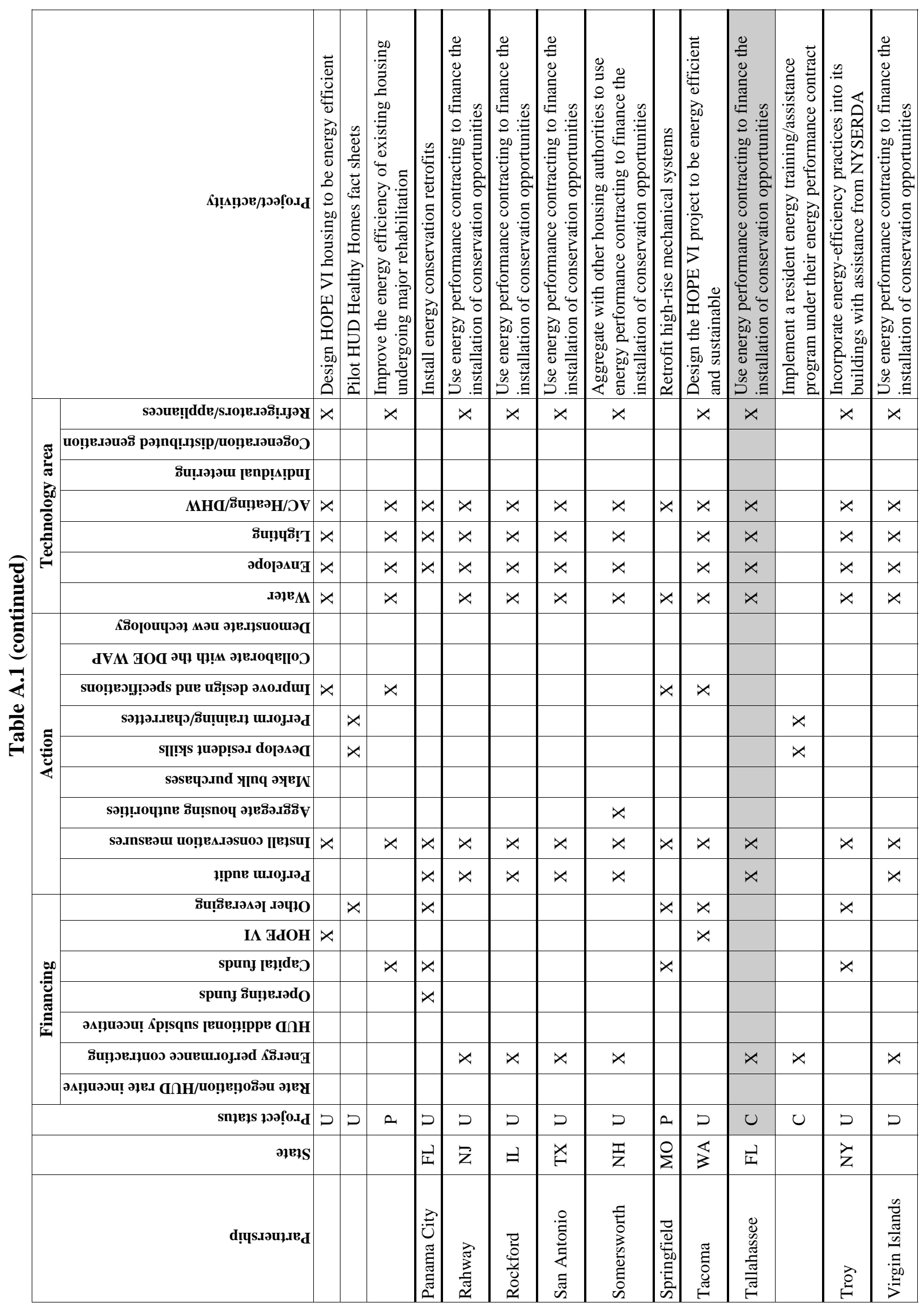









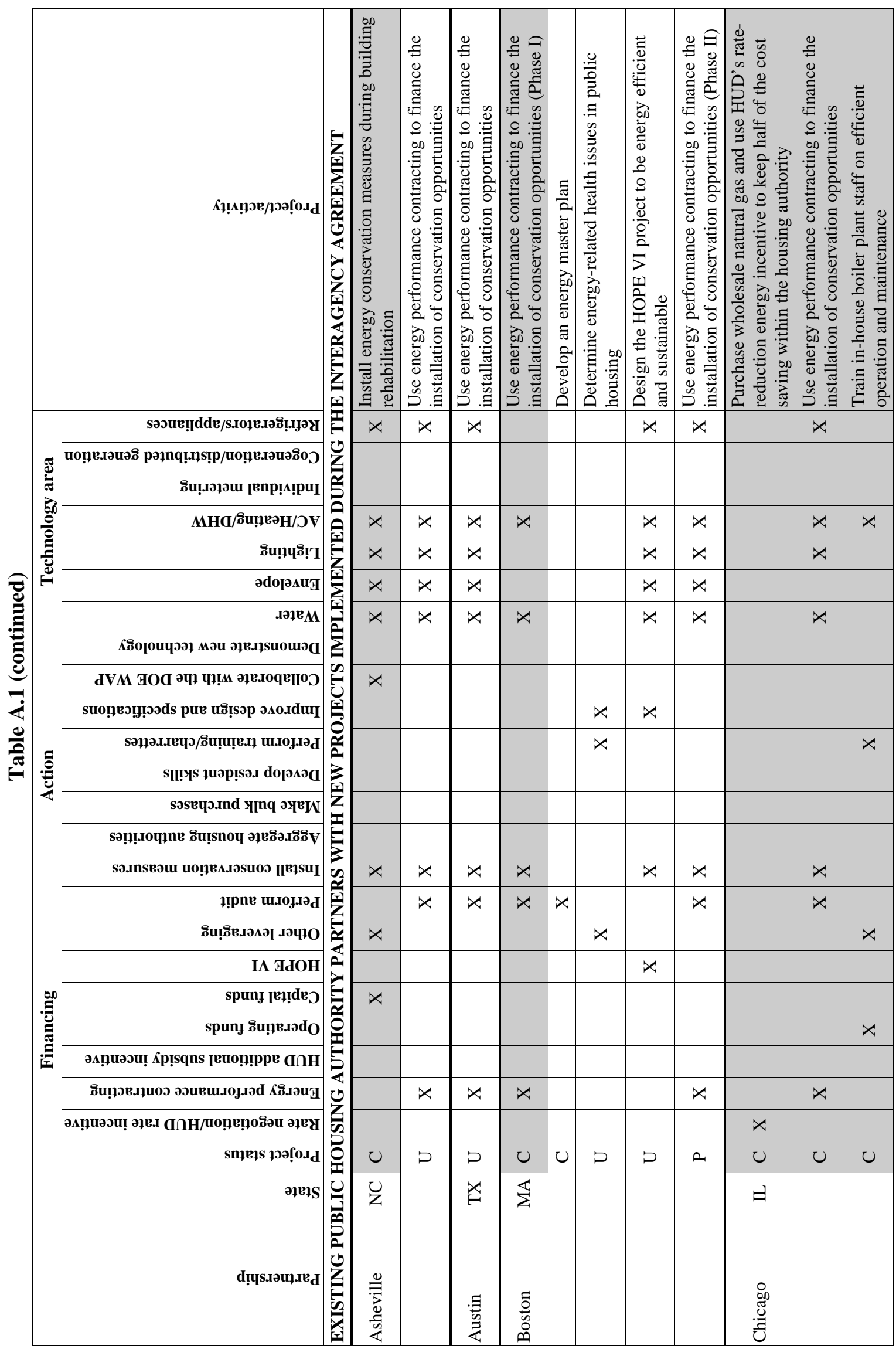




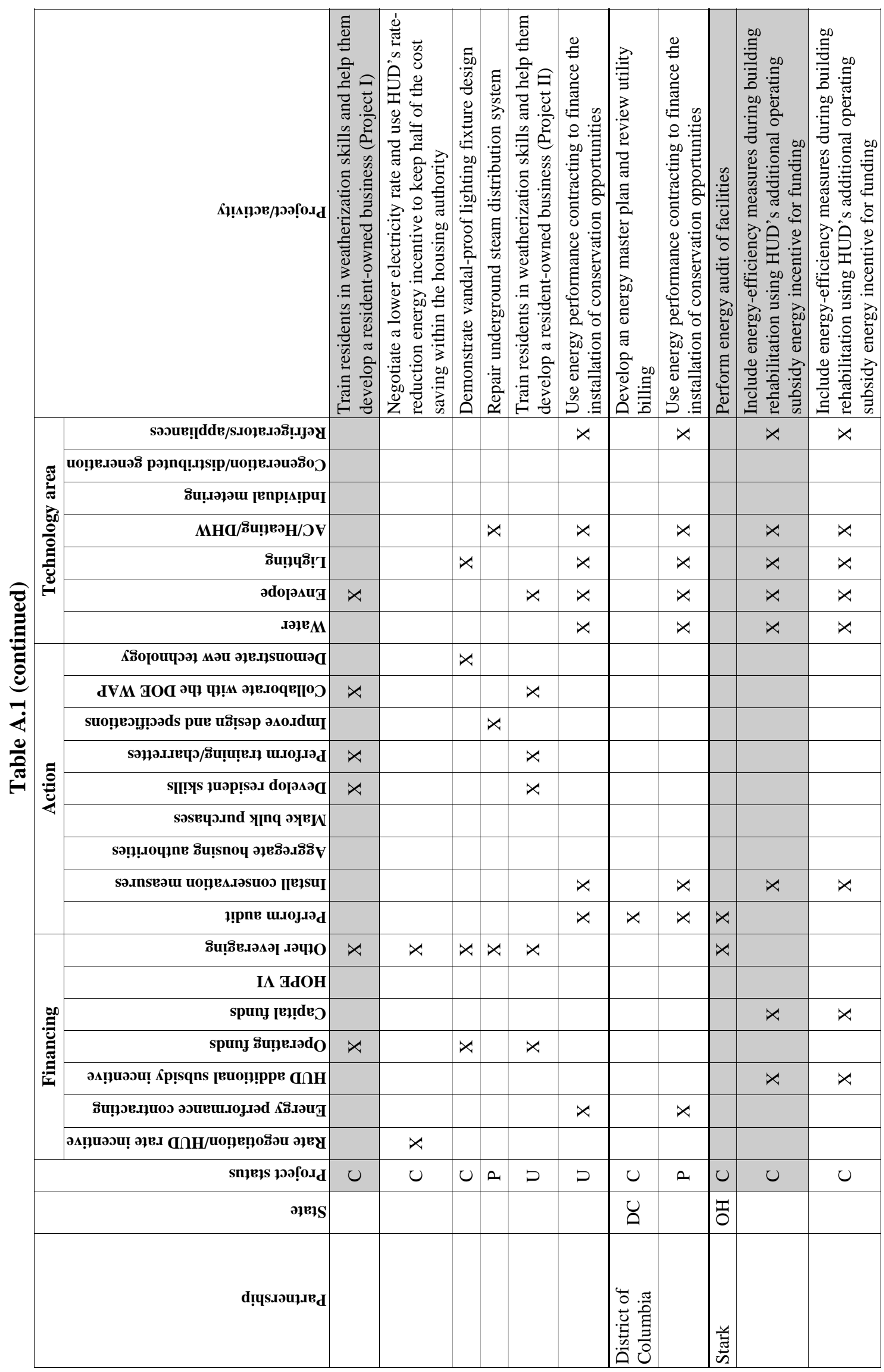




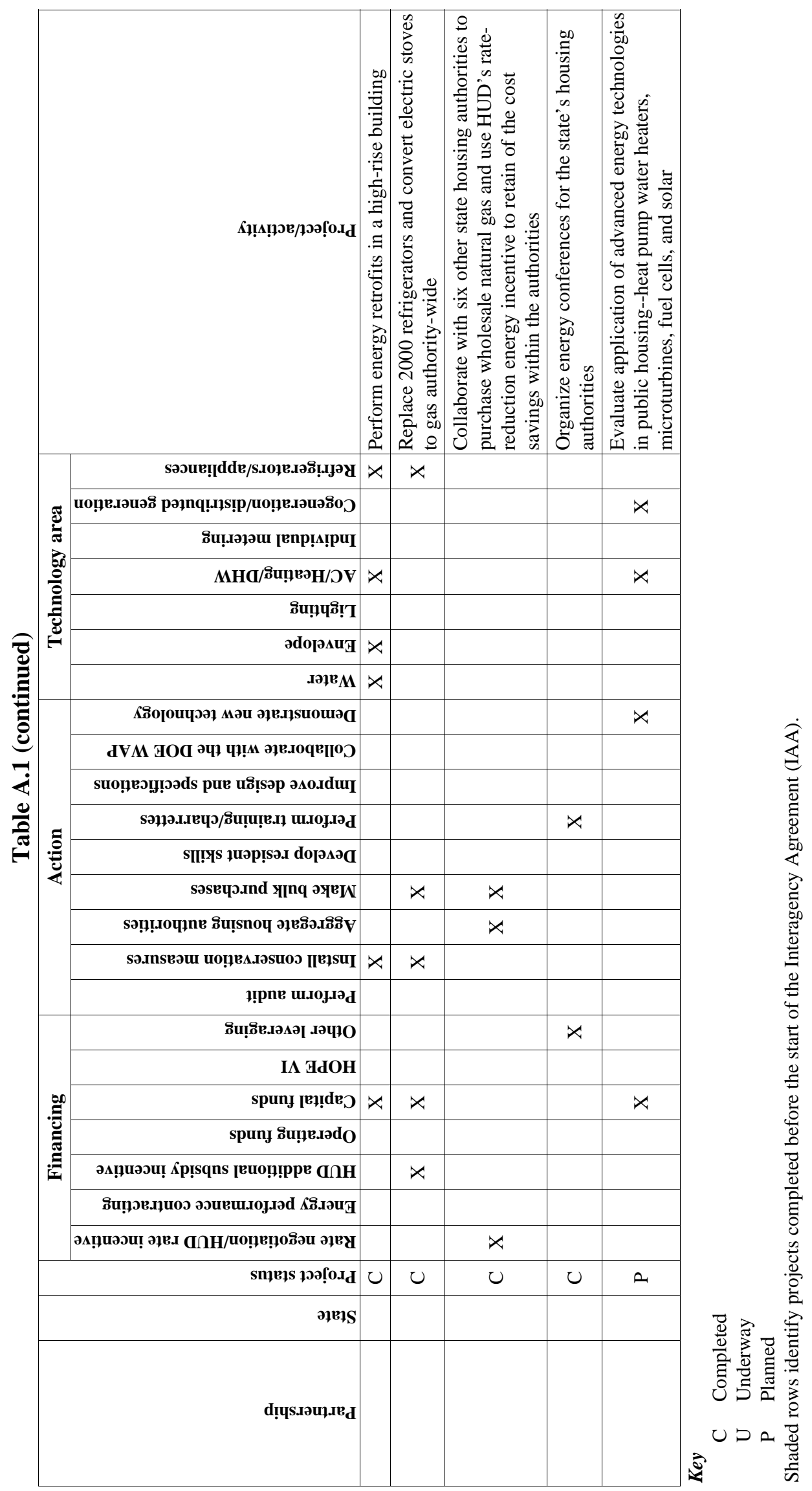





\section{Appendix B: Summary of Conferences, Workshops, and Training}

During the term of the IAA, Rebuild America made numerous presentations to housing authorities on energy efficiency opportunities and solutions and provided energy training on selected topics at various conferences and workshops. This appendix provides details on each event. The conferences and workshops are reported in four sections-HUD PIH conferences, NAHRO conferences and meetings, other housing organization events, and Rebuild America events.

\section{HUD's Office of Public and Indian Housing Conferences}

\section{Resident Leader Training Conference, Dallas, Texas, April 2001}

Rebuild America organized two sessions for resident leaders on what they can do to help in energy conservation, including a discussion of utility allowances, utility metering, HUD's energy incentives, Public Housing Authority plans, and training opportunities. Rebuild America delivered a technical presentation at these sessions, and the Chicago Housing Authority also presented a case study of its activity. Approximately 60 people attended each of the two sessions.

Rebuild America also developed written material for these two sessions that was included in the conference notebooks.

\section{PHA Staff Training Conference, Washington, D.C., August 2001}

Rebuild America organized two workshops that were given on two separate days (four sessions total) on how to manage energy costs and how to train residents to conserve energy.
The first workshop covered utility bills, metering options, utility allowances, and HUD's energy incentives; the second workshop discussed training opportunities, types of training, implementation, and resources. Rebuild America delivered a technical presentation at each session, and the Chicago Housing Authority also presented a case study of its activity. Approximately 50 to 75 people attended each of the four sessions.

Rebuild America also developed written material for the two workshops that was included in the conference notebooks.

\section{NAHRO Conferences and Meetings}

\section{National Conference, Phoenix, Arizona, November 2000}

Rebuild America provided a booth in the exhibitor's hall in which energy issues with individual housing authorities were discussed, the Rebuild America Program was described, and potential Rebuild America partners were identified.

\section{North Central Regional Conference/Ohio Housing Authority Conference, Cleveland, Ohio, April 2001}

Rebuild America made a presentation on successful energy projects performed in public housing, which highlighted several Rebuild America partnerships. Stark Metropolitan Housing Authority presented a specific case study on its energy-related activities. The National Center for Appropriate Technology (NCAT) made a general presentation on energy usage in public housing and on the 
Public and Indian Housing Energy

Clearinghouse. These presentations were attended by about ten people.

Mid-Atlantic Regional Conference, Pittsburgh, Pennsylvania, April 2001

Rebuild America developed and delivered a workshop that addressed energy efficiency, HUD's energy incentives, and the Rebuild America program. A second speaker made a presentation on green building issues. The workshop was attended by seven people.

\section{Pacific-Northwest Regional Conference, Seattle, Washington, April 2001}

Rebuild America presented a workshop on energy efficiency, HUD's energy incentives, and the Rebuild America program. The workshop was attended by about ten people.

\section{Pacific Southwest Region Meeting of the Development, Modernization, and Maintenance Officers, Santa Clara, California, May 2001}

Rebuild America participated in this meeting of Development, Modernization, and Maintenance Officers from California and Nevada housing authorities. Performance contracting was the focus of this meeting, with presentations being made by two energy service companies. Rebuild America made a short presentation and participated in the discussions. About 25 of the member housing authorities were in attendance at this meeting.

\section{Southeast Regional Conference, Ft. Lauderdale, Florida, July 2001}

Rebuild America delivered a presentation at the conference plenary on energy efficiency, capital planning, and the Rebuild America program. Approximately 60 people were in attendance for the talk.

\section{Pacific Southwest Region Meeting of the Development, Modernization, and Maintenance Officers, Reno, Nevada, September 2001}

Rebuild America participated in this meeting of Development, Modernization, and Maintenance Officers from about 50 California and Nevada housing authorities. During these meeting, photovoltaic systems were discussed. About 25 of the member housing authorities were in attendance at this meeting.

\section{National Conference, Nashville, Tennessee, October 2001}

Rebuild America organized a technical session on energy that was attended by approximately 25 people. Rebuild America made a presentation on energy challenges and strategies for public housing and addressed energy bills, metering options, utility allowances, HUD's energy incentives, HOPE VI, and Rebuild America case studies. The CEE made a copresentation on lighting, appliances, ENERGY STAR, and bulk purchasing.

Rebuild America also provided a booth in the exhibitor's hall where energy issues with individual housing authorities were discussed, the Rebuild America Program was described, and potential Rebuild America partners were identified.

\section{Southeast Regional Conference, Asheville, North Carolina, November 2001}

Rebuild America organized a workshop on lighting technology, energy audits, and capital planning. Lithonia Lighting (a Rebuild America business partner) made a technical presentation and two local Rebuild America partnerships-Asheville Community Action Agency and Salisbury Housing Authoritypresented case studies. Approximately 25 people attended the workshop. 
National Conference, Seattle, Washington, October 2002

Rebuild America organized a technical session on better performing housing and energy efficiency. The Oakland Housing Authority and the Sustainable Housing Innovation Partnership (a Rebuild America partner) made presentations during this workshop. Approximately 60 people were in attendance.

\section{Other Events of Housing Organizations}

\section{New Hampshire State Directors Association Meeting, Concord, New Hampshire, April 2001}

Rebuild America delivered a presentation at the conference plenary on energy efficiency, capital planning, utility rate reductions under deregulation, and the Rebuild America program. About 25 people were in attendance for the talk.

\section{Missouri State Directors Association Meeting, Sedalia, Missouri, May 2001}

Rebuild America delivered a presentation on energy efficiency, capital and operations planning, and the Rebuild America program. Fifteen people attended the presentation.

\section{PHADA Annual Convention, Portland, Oregon, May 2001}

Rebuild America made a technical presentation that highlighted HUD's energy incentives and how several Rebuild America Partnerships have approached improving energy efficiency in public housing. The presentation was attended by about 10 people.

\section{National Low-Income Energy Conference, Cincinnati, Ohio, June 2001}

Rebuild America presented an overview of the program. Stark Metropolitan Housing
Authority and Asheville Housing Authority presented case studies of their recent energyrelated activity. About 15 people attended the session.

\section{Affordable Comfort Conference, Cincinnati, Ohio, April 2002}

DOE and Rebuild America cosponsored this conference on energy efficiency technology in housing. Sessions and short courses on healthy housing and multifamily buildings were especially appropriate to public housing.

As part of the conference, Rebuild America worked with HUD's Healthy Homes Program and others to sponsor a full-day workshop on high-performance public housing, which highlighted the work being done by the Boston Housing Authority. The workshop brought together 50 people from around the United States to address issues of healthy and energyefficient public housing, and the relationship of health issues and energy-efficiency conditions and improvements. The participants in the workshop included HUD officials, public housing residents and managers, public health specialists, and energy researchers and practitioners.

The goal of the workshop was to discuss the areas of highest concern in creating healthy environments and to identify the steps needed to realize them. The workshop focused on the specifics of health and safety in public housing in four key areas:

- resident health and safety standards,

- operations and maintenance,

- major renovations, retrofits, and energy upgrades, and

- new construction.

Breakout groups on each of these topics explored major health and safety issues that should be addressed and considered whether current regulations and practices support or 
inhibit the ability of residents and owners to address these issues. The groups made procedure and policy recommendations to improve the health and safety of public housing residents while increasing building performance. Ideas generated include establishing resident's rights and responsibilities for resident health; reintegrating maintenance with building owners and residents to improve education and accountability; performing comprehensive health and energy assessments using standardized audits and teams composed of public health officials, residents, and maintenance staff; and incorporating healthrelated measures in retrofit and new projects by holding design charrettes and specifying measurable performance goals.

\section{National Multifamily Building Efficiency Conference, New York, New York, June 2003}

Rebuild America is helping to plan this conference that is being sponsored by NYSERDA, DOE, HUD Healthy Homes, and perhaps HUD PIH. Rebuild America's involvement in this conference identified the opportunity for HUD PIH to participate in the conference and provide a technical training resource to housing authorities.

\section{Rebuild America Events}

\section{National Forum, Atlanta, Georgia, March 2001}

This Rebuild America conference was held for all its partnerships, business partners, strategic partners, and state energy offices. Tracks discussing technology, collaboration, and financing were offered to all participants. In particular, a session attended by about 25 people focused on the public housing market sector and discussed approaches and opportunities for drawing public housing authorities into community partnerships.

\section{Energy Performance Contracting Workshop for Public Housing Authorities, Chicago, Illinois, June 2001 and June 2002}

Rebuild America cosponsored a week-long training workshop on energy performance contracting in public housing with the Illinois Office of HUD and two Rebuild America Strategic Partners-NAHRO and NAESCO. Similar workshops were provided in 1999 and 2000. In 2001, the workshop was attended by 43 people -23 housing authority staff members representing 20 different authorities, 12 energy service company employees from 9 different companies, 6 HUD staff from 6 different field offices, and 2 people not associated with public housing. In 2002, 47 people attended the workshop-35 housing authority staff members representing 25 different housing authorities, 7 energy service company employees representing 4 different companies, and 5 HUD staff. Workshop materials were provided to numerous other housing authority and energy service company staff.

\section{National Forum, New Orleans, Louisiana, July 2002}

This Rebuild America conference was held for all its partnerships, business partners, strategic partners, and state energy offices. Tracks discussing technology, collaboration, and financing were offered to all participants. In particular, a session focused on energy efficiency challenges and successes in public and affordable housing. Two other sessions addressed financing efficiency in residential buildings and ways that DOE's Building America and ENERGY STAR programs can help achieve residential energy efficiency.

\section{Effective Approaches to Improving Energy Efficiency in Public Housing, Canton, Ohio, September 2002}

The Ohio Rebuild America Program and Stark Metropolitan Housing Authority sponsored 
this conference that brought together housing authorities, HUD staff, and others within the state of Ohio to explore opportunities to improve the energy efficiency of public housing. Rebuild America made a presentation on energy efficiency opportunities in public housing. The conference was attended by 59 people, with representatives from 12 different housing authorities attending. 

ORNL/TM-2003/12

\section{INTERNAL DISTRIBUTION}

1. M. A. Brown

2. J. E. Christian

3. W. G. Craddick

4. E. C. Fox

5. J. M. MacDonald

6. C. I. Moser
7. T. R. Sharp

8. R. L. Shelton

9-58. M. P. Ternes

59. R. L. Wendt

60. Central Research Library

61. ORNL Laboratory Records-RC

\section{EXTERNAL DISTRIBUTION}

62. Greg Andrews, U.S. Department of Energy, 75 Spring Street, Suite 200, Atlanta, GA 30303

63. Manny Anunike, Ohio Department of Development, 77 South High Street, Floor 26, P.O. Box 1001, Columbus, OH 43216-1001

64. Pat Arnaudo, U.S. Department of Housing and Urban Development, PC/Room 4222, 451 7th Street S.W., Washington, DC 20410

65. Michael Arny, Energy Services Coalition, 1526 Chandler Street, Madison, WI 53711

66. Mark Bailey, EE-2K/Forrestal Building, U.S. Department of Energy, 1000 Independence Ave. S.W., Washington, DC 20585

67. Norman Bair, Wisconsin Energy Bureau, P.O. Box 7868, Madison, WI 53707-7868

68. Ken Baker, Aspen Systems Corporation, 1301 North Orchard Street, Boise, ID 83706

69. Richard Baldauf, South Carolina Energy Office, 1201 Main Street, Suite 820, Columbia, SC 29201

70. Doug Baston, Northeast by Northwest, 18 Sheepscot Road, Alna, ME 04535

71. Toby Benson, State of Montana, Department of Environmental Quality, 1520 East 6th Avenue, Helena, MT 59620-0901

72. Kirk Bond, Aspen Systems Corporation, 7815 North Adrian Avenue, Kansas City, MO 64151-8202

73. Jeff Brown, Aspen Systems Corporation, 241 West Washington Street, Nashville, NC 27856

74. Sonia Burgos, U.S. Department of Housing and Urban Development, PES/Room 4206, 451 7th Street S.W., Washington, DC 20410

75. Jennifer Chiodo, Vermont Energy and Investment Corporation, 255 South Champlain Street, Burlington, VT 05401

76. Kim Christianson, State of North Dakota, Division of Community Services, 600 East Boulevard, State Capitol, 14th Floor, Bismark, ND 58505-0170

77. Heather Clark, NYSERDA, 17 Columbia Circle, Albany NY 12203

78. Carla Clemons, U.S. Department of Energy, One South Wacker Drive, Suite 2380, Chicago, IL 60606-4616

79. Dennis Clough, 14 Wrightson Ave., Easton, MD 21601

80. Ed Cobham, Florida Department of Community Affairs, 2555 Shumard Oak Boulevard, Tallahassee, FL 32399-2100 
81. Patrick Condon, Rhode Island State Energy Office, One Capitol Hill, Providence, RI 02908

82. Sharon Cooke, District of Columbia Energy Office, 2000 14th Street NW, Suite 300 East, Washington, DC 20009

83. Cyane Dandridge, Strategic Energy Innovations, 175 North Redwood Drive, Suite 150, San Rafael, CA 94903

84. Greg Davoren, U.S. Department of Energy, JFK Federal Building, Suite 675, Boston, MA 02203-0002

85-89. Rick Diamond, Lawrence Berkeley National Laboratory, One Cyclotron Road, MS 90-3074, Berkeley, CA 94720

90. Luke Elliot, Arkansas Energy Office 3321 Jimmy Creek Road, Fox, AR 72051

91. Terry Ellis, Tennessee Department of Economic and Community Development, Rachel Jackson Building, 320 Sixth Avenue North, 6th Floor, Nashville, TN 37243-0405

92. Dave Engel, U.S. Department of Housing and Urban Development, RRT/Room 8134, 451 7th Street S.W., Washington, DC 20410

93. Steve Ewing, Stark Metropolitan Housing Authority, 400 East Tuscarawas Street, Canton, $\mathrm{OH} 44702-1131$.

94. Denis Feck, EE-2K/Forrestal Building, U.S. Department of Energy, 1000 Independence Ave. S.W., Washington, DC 20585

95-99. Michael Freedberg, U.S. Department of Housing and Urban Development, RRT/Room 8130, 451 7th Street S.W., Washington, DC 20410

100. Rebecca Garrett, Alaska Energy Authority, 813 West Northern Lights Boulevard, Anchorage, AK 99503

101. Joan Gregerson, P.O. Box 821, Niwot, CO 80544

102-106. Bob Groberg, U.S. Department of Housing and Urban Development, DPVE/Room 7250, 451 7th Street S.W., Washington, DC 20410

106-110. Susan Guard, U.S. Department of Energy, 100 Penn Square East, Suite 890, The Wanamaker Building, Philadelphia, PA 19107-3396

111. Cindy Gunn, Aspen Systems Corporation, 3 Ledge Circle, Concord, NH 03301

112. Steve Harding, State of South Dakota, 711 East Wells Avenue, Pierre, SD 57501-3369

113. Lois Jackson, State of Vermont, Energy Efficiency Division, 112 State Street, Drawer 20, Montpelier, VT 05620

114. Nick Keller, Aspen Systems Corporation, 2277 Research Blvd., MS 6Z, Rockville, MD 20850

115. Linda King, Aspen Systems Corporation, 1229 SW Creston Avenue, Des Moines, IA 50315

116. Peter Konesky, State of Nevada, Department of Business and Industry, 727 Fairview Drive, Suite F, Carson City, NV 89701

117. Deborah Lamm, Aspen Systems Corporation, 241 West Washington Street, Nashville, NC 27856

118. Kelly Launder, Michigan Department of Consumer and Industry Services, 6545 Mercantile Way, Suite 9, Lansing, MI 48909

119. Pat LeDonne, EE-2K/Forrestal Building, U.S. Department of Energy, 1000 Independence Ave. S.W., Washington, DC 20585

120. Greg Lenaghan, Illinois Department of Commerce and Community Affairs, 620 East Adams Street, Springfield, IL 62701-1615 
121. Nina Lockhart, National Association of Energy Service Companies, 1615 M Street NW, Suite 800, Washington, DC 20036

122. Bernell Loveridge, Utah Energy Office, 1594 West North Temple \# 3610, Salt Lake City, UT 84114-6480

123. Clarence Mann, Alabama Department of Economic and Community Affairs, 401 Adams Avenue, Montgomery, AL 36104

124. Eileen McHugh, State of Massachusetts, 70 Franklin Street, 7th Floor, Boston, MA 02110-1313

125. Jim McTish, Pennsylvania Department of Environmental Protection, 555 North Lake, Suite 6010, Conshohoken, PA 19428

126. Betty Merrill, Oregon Energy Office, 625 Marion Street NE, Salem, OR 97301-3742

127. Karen Messmer, Washington State University, 925 Plum Street SE, Building 4, Olympia, WA 98504-3165

128. John Millhone, EE-2K/Forrestal Building, U.S. Department of Energy, 1000 Independence Ave. S.W., Washington, DC 20585

129. Bill Mixon, TECH Support Services, 310 Timberline Drive, Kingston, TN 37763

130. Cynthia Moseley, North Carolina Department of Commerce, Energy Division, 1340 Mail Service Center, Raleigh, NC 27699

131. Christina Mudd, Maryland Energy Office, 1623 Forest Drive, Annapolis, MD 21403

132. Mike Myers, Aspen Systems Corporation, 2624 Neimann Drive, Austin, TX 78748

133. Alan Nagle, Aspen Systems Corporation, 1617 Cole Boulevard, MS 1521, Golden, CO 80401-3393

134. Michael Nail, National Association of Housing and Redevelopment Officials, 630 Eye Street NW, Washington, DC 20001

135. Dee NaQuin-Shafer, National Association of Housing and Redevelopment Officials, 630 Eye Street NW, Washington, DC 2001

136. John Nunley III, Wyoming Business Council, 214 West 15th Street, Cheyenne, WY 82002

137. Annette Osso, Virginia Housing and the Environmental Network, P.O. Box 6539, Arlington, VA 22206

138. Bob Painter, Missouri Department of Natural Resources, 4750 Troost, Kansas City, MO 64166

139. Terry Pease, State of Wisconsin, Department of Administration, 101 East Wilson Street, 6th Floor, Madison, WI 53703

140. Vince Pedicini, New Jersey Board of Public Utilities, Two Gateway Center, 9th Floor, Newark, NJ 07102

141-165. Matt Pesce, Aspen Systems Corporation, 4414 Galleria Pointe Circle, Rock Hill, SC 29730

166. Jim Ploger, Kansas Corporation Commission, 1500 Southwest Arrowhead Road, Topeka, KS 66604-4027

167. Melvin Powers, Aspen Systems Corporation, 241 West Washington Street, Nashville, NC 27856

168. Richard Putnam, U.S. Department of Energy, 800 5th Street, Suite 3950, Seattle, WA 98104

169-173. Elise Rand, Potomac Communications Group, 2025 M Street NW, Suite 350, Washington, DC 20036

174. John Ruckes, Connecticut State Energy Office, 450 Capital Avenue, MS 52ENR, Hartford, CT 06106-1308 
175. Bill Russell, U.S. Department of Housing and Urban Development, P/Room 4100, 451 7th Street S.W., Washington, DC 20410

176-200. Dick Santangelo, U.S. Department of Housing and Urban Development, PES/Room 4206, 451 7th Street S.W., Washington, DC 20410

201. Sue Seifert, Idaho Department of Water Resources, 1301 North Orchard, Boise, ID 83706

202. Ann Selzer, Nebraska Energy Office, 1111 O Street, Suite 223, Lincoln, NE 68509-5085

203. Elizabeth Shirakh, California Energy Commission, 1516 9th Street, MS 26, Sacramento, CA 95814

204. Terry Singer, National Association of Energy Service Companies, 1615 M Street NW, Suite 800, Washington, DC 20036

205. Linda Smith, Governor's Office of Energy Management and Conservation, 225 East 16th Avenue, Suite 650, Denver CO 80203

206. Brevan Smith, Virgin Islands Energy Office, 200 Strand Street, Fredericksted, VI00840

207. John Snell, Peregrine Energy Group, 77 North Washington Street, Boston, MA 02114

208. Rebecca Spiess, Iowa Department of Natural Resources, 502 East 9th, Des Moines, IA 50319

209. Kirk Stone, New Hampshire Office of Energy and Community Service, 57 Regional Drive, Suite 3, Concord, NH 03301

210-234. Dan Sze, EE-2K/Forrestal Building, U.S. Department of Energy, 1000 Independence Ave. S.W., Washington, DC 20585

235. Dub Taylor, Texas State Energy Conservation Office, LBJ State Office Building, 111 East 17th Street, Room 1114, Austin, TX 78774

236. Harold Trujillo, New Mexico Department of Energy, Minerals, and Natural Resources, P.O. Box 1948, Santa Fe, NM 87505

237. Verlina Underwood, Mississippi Development Authority, State Energy Division, P.O. Box 849, Jackson, MS 39205

238. Dave Waltzman, U.S. Department of Energy, 1617 Cole Boulevard, MS 1521, Golden, CO 80401

239. Jim Westberg, Arizona Department of Commerce, State Energy Office, 3800 North Central Avenue, Suite 1400, Phoenix, AZ 85012

240. Michael Williams, Stark Metropolitan Housing Authority, 400 East Tuscarawas Street, Canton, OH 44702-1131.

241. Gavin Williams, Indiana Department of Commerce, One North Capitol, Suite 700, Indianapolis, IN 46204

242. Bill Willis, West Virginia Development Office, State Capitol Complex, Building 6, Room 645, Charleston, WV 25305

243. Eileen Yoshinaka, U.S. Department of Energy, P.O. Box 50168, 300 Ala Moana Boulevard, Room 4-131, Honolulu, HI 96850

244. Charles Young, Aspen Systems Corporation, 241 West Washington Street, Nashville, NC 27856

245. Geoff Young, Kentucky Department for Natural Resources, Division of Energy, 663 Teton Trail, Frankfort, KY 40601 